\title{
(III norden
}

\section{Selfoss Declaration Achievements Report}

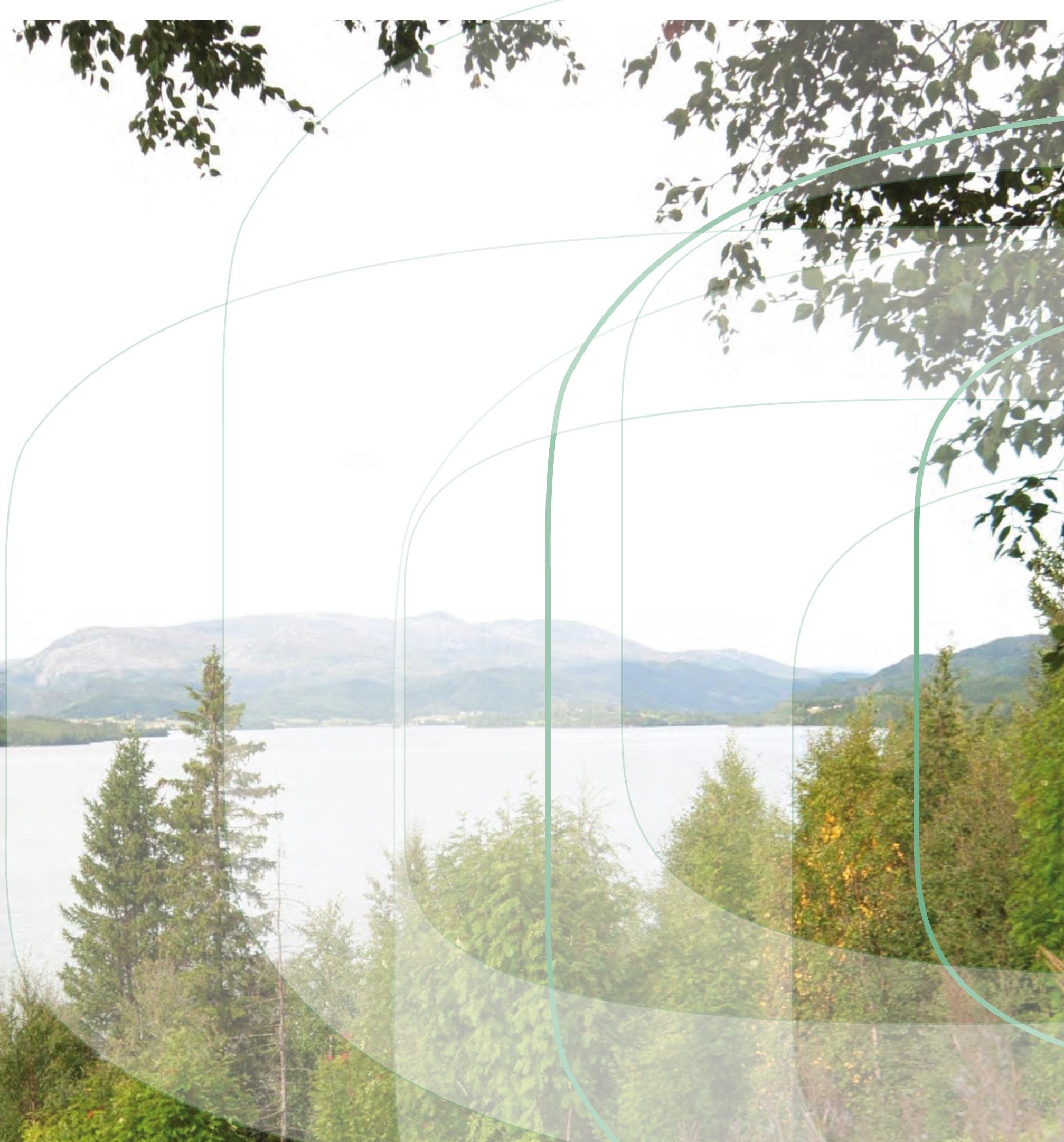



2 norden 



\section{Selfoss Declaration Achievements Report}

Edda Sigurdis Oddsdottir 
Selfoss Declaration Achievements Report Edda Sigurdis Oddsdottir

ISBN 978-92-893-3802-8 (PRINT)

ISBN 978-92-893-3804-2 (PDF)

ISBN 978-92-893-3803-5 (EPUB)

http://dx.doi.org/10.6027/TN2014-555

TemaNord 2014:555

ISSN 0908-6692

(C) Nordic Council of Ministers 2014

Layout: Hanne Lebech

Cover photo: Edda Sigurdis Oddsdottir

Photo: Edda Sigurdis Oddsdottir

Print: Rosendahls-Schultz Grafisk

Printed in Denmark

This publication has been published with financial support by the Nordic Council of Ministers. However, the contents of this publication do not necessarily reflect the views, policies or recommendations of the Nordic Council of Ministers.

\section{www.norden.org/en/publications}

Nordic co-operation

Nordic co-operation is one of the world's most extensive forms of regional collaboration, involving Denmark, Finland, Iceland, Norway, Sweden, and the Faroe Islands, Greenland, and Åland.

Nordic co-operation has firm traditions in politics, the economy, and culture. It plays an important role in European and international collaboration, and aims at creating a strong Nordic community in a strong Europe.

Nordic co-operation seeks to safeguard Nordic and regional interests and principles in the global community. Common Nordic values help the region solidify its position as one of the world's most innovative and competitive.

\section{Nordic Council of Ministers}

Ved Stranden 18

DK-1061 Copenhagen K

Phone (+45) 33960200

www.norden.org 


\section{Contents}

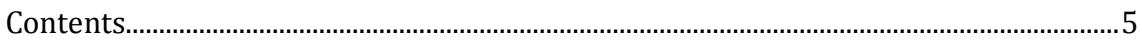

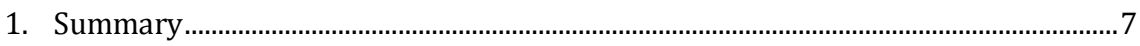

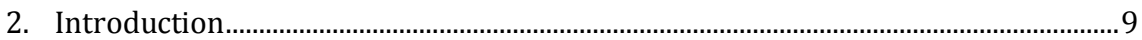

3. The Selfoss Declaration and its Implementation...................................................... 11

4. The Achievements of Selfoss Declaration ................................................................... 17

5. Reflection on Measures, Activities and their Impact................................................. 19

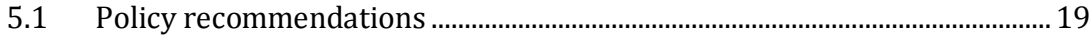

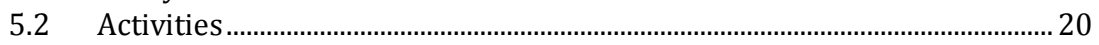

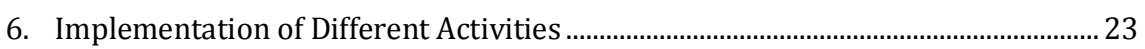

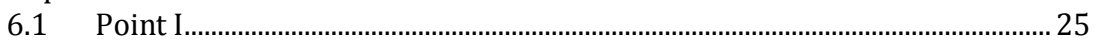

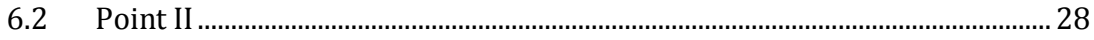

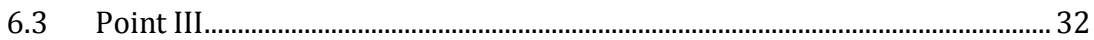

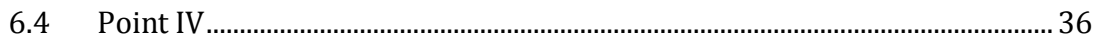

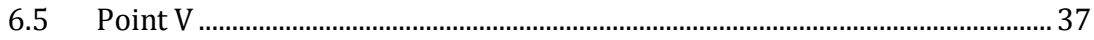

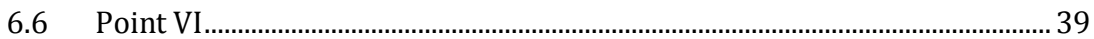

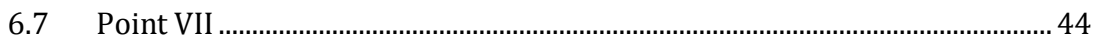

6.8 Point IIX

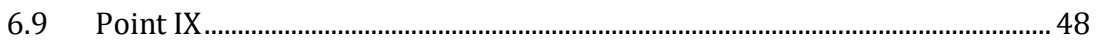

7. Overall Reflections ……………............................................................................. 51

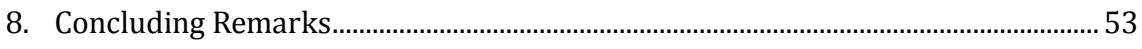

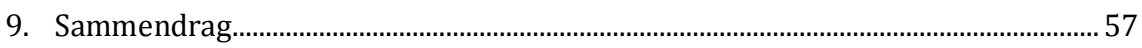

10. Appendix: Letter to SNS secretariat, NordGen Forest, members of EKFJLS skog and the NMR office, emailed in January 2014 



\section{Summary}

In 2008, the Ministers of Forestry in the Nordic countries made the Selfoss Declaration on sustainable forestry in the Nordic region, emphasizing the importance of the forest when facing global climate change and its importance for biodiversity, recreation and as a resource for economic development. In a report published within the TemaNord series, an ad-hoc committee gave recommendations on how to implement the intention of the declaration. The recommendations were two-fold, policy recommendations to the Nordic co-operation structures and more direct measures that included different activities to be undertaken by different Nordic actors.

The current report aims to reflect on the achievements of the Selfoss Declaration and the following report. The question is, did the forestry sector focus on the resolution that the forestry ministers acknowledged in the Declaration and furthermore, how did it affect the forestry sector in the Nordic countries. The focus in this report is on activities that were performed by SNS or NordGen Forest or have been financed with funds from the Nordic Council of Ministers.

More than 20 actvities took place, directly following up on the resolution points listed in the Selfoss Declaration. The outcomes of these activities are variable and with diverse accessibility but for the majority, final reports can be found online and in many cases, papers in peer-reviewed journals are also available. It seems to be a general opinion that the Selfoss Declaration initiated a lot of activities and incisive actions in organizing the forest research cooperation across national boundaries within the Nordic countries. The initiation of new networks and the continuation of older ones facilitated exchange of ideas and strengthened the co-operation of scientists within specific fields in the Nordic and neighbouring countries. 
The key to a successful operation is a clear vision, which in the case of the Selfoss Declaration was outlined by the Nordic forestry ministers. The follow-up work of the ad-hoc committee and publication of the recommendations facilitated and encouraged Nordic organizations to incorporate and carry out projects in harmony with the vision. Based on this experience, it seems important that the forestry ministers continue to take an active part in visualizing where Nordic cooperation should head in the future. 


\section{Introduction}

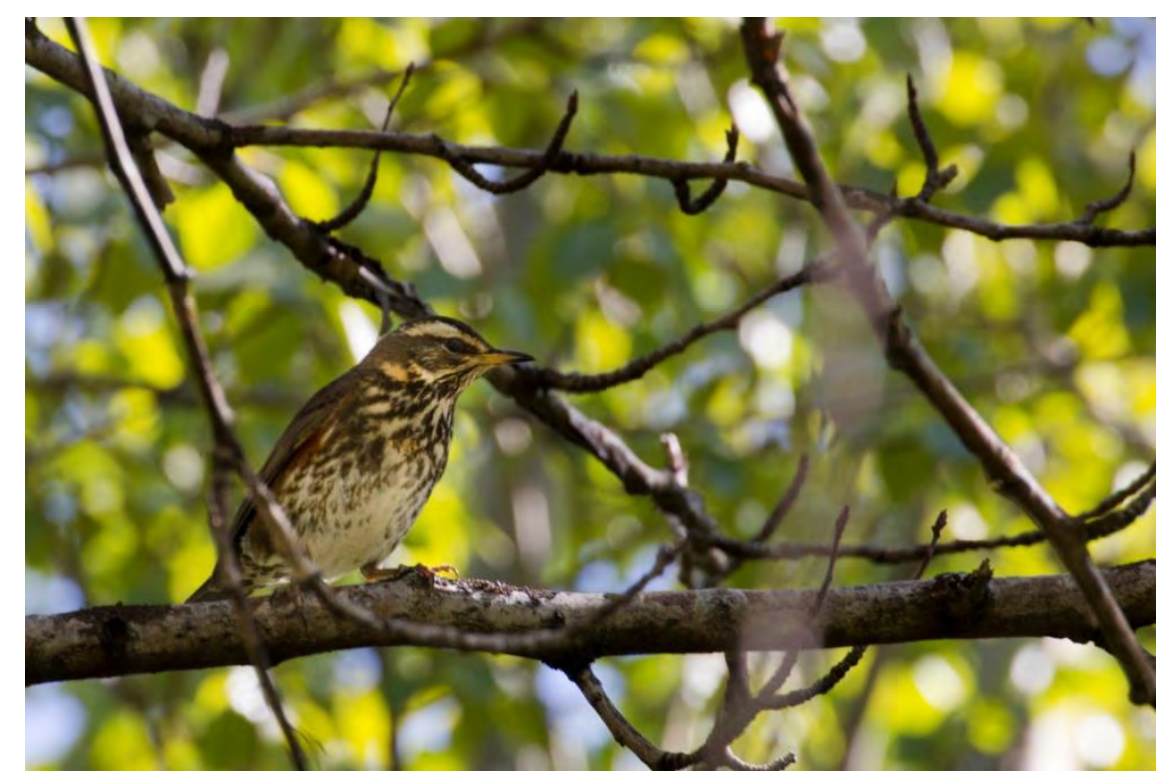

Forestry is an important sector in the Nordic countries and a sector where Nordic countries have a strong international position. Finland, Norway and Sweden are among the most important producers of forest products and services worldwide, and have extensive forest cover, up to $75 \%$ of land area. Denmark and Iceland, however, are in the process of afforestation of their land area. Denmark has already reached the goal of having important income from their forests and Iceland has a small but steadily growing forestry-based income. Boreal conifer forests dominate the Nordic region, but Denmark and southern part of Sweden have some temperate forests. Nordic forestry cooperation focuses both on local and regional importance of forests within the region, and on promoting economic, ecological, social and cultural values. In the Nordic countries, forestry has followed the principle of sustainable management, based on forest research of high international quality.

Within the Nordic Council of Ministers (NMR), forestry topics belong to the ministerial council for fisheries and aquaculture, agriculture, food and forestry (MR-FJLS). There is a specific council of senior officials on forestry, EK-FJLS skog, that is responsible for Nordic forest cooperation. 
Following the decisions of EK-FJLS skog, two key bodies are responsible for the delivery of Nordic Forest Cooperation; NordGen Forest serves as a Nordic meeting place to examine issues in the fields of forest genetics and genetic resources, supply of seeds and plants, and methods for regeneration, and SNS (Nordic Forest Research Co-operation) that facilitates forest research and networking of forest researchers in the Nordic countries. Furthermore, SNS is in close collaboration with EFI (European Forest Institute) on EFINORD (The North European Regional Office of EFI) and aims to strengthen forest research and networks in Northern Europe. The Nordic forestry cooperation also provided the basis for the creation of the the flagship project "Sustainable Forest Management in the Baltic Sea Region - EFINORD" in the EU Strategy for the Baltic Sea Region (EUSBSR). The flagship offers an umbrella for forest and sustainable forest management activities under priority area AGRI and promotes sustainable forestry within the EUSBSR action plan. 


\section{The Selfoss Declaration and its Implementation}

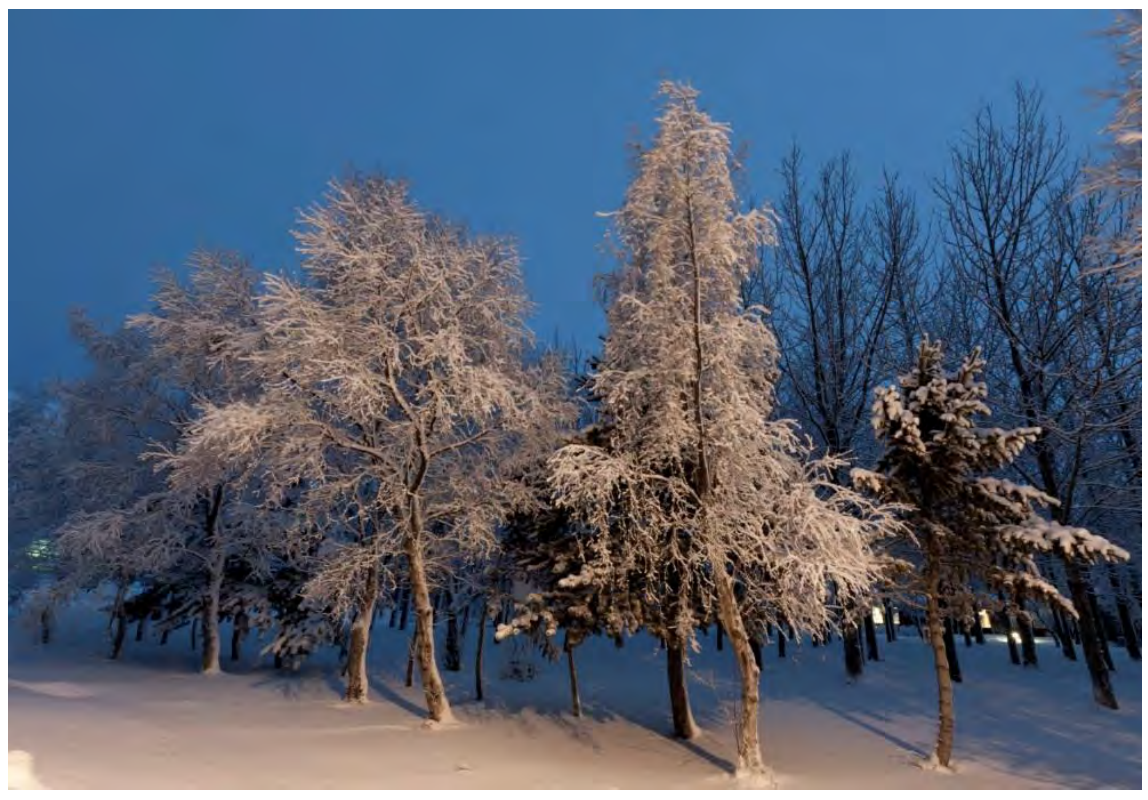

The Selfoss Declaration (SD) is a declaration on sustainable forestry, made by the Nordic ministers responsible for forestry in August 2008 at a conference in Selfoss, South Iceland. In that declaration, the many values and functions of forests in the Nordic Region were emphasized, including importance of the forest in facing global climate change and global administration of freshwater resources. Furthermore, its importance for biodiversity, recreation, and as a resource for economic development was stressed and the ministers highlighted their priorities in 9 points.

The Nordic Council of Ministers - The Ministers of Forestry. Ministerial declaration adopted in Selfoss, Iceland 19. august 2008 At their meeting of 19th August 2008 in Selfoss, Iceland, the forestry ministers from Denmark, Finland, Iceland, Norway, Sweden and Åland discussed sustainable forestry, with the focus on water and the climate. 
The use of the Nordic forests has had unique significance for the development of the Nordic welfare society.

The people of the Nordic Region have a close relationship with the forest. Since the beginning of time, the forest has provided mankind with protection, material for houses and buildings, energy and food from plants and game. In the modern era, the Nordic forests constitute a resource for economic development in the Nordic Region. The forest is also important for bio-diversity and recreation. This shows very clearly the forest's many values and functions.

The forest is linked to two of the most important environmental challenges of our time: global climate change and the global administration of freshwater resources. The Nordic forestry ministers - who were gathered for a conference in Selfoss, Iceland, on 18-19th August 2008 - want to highlight the importance of the forest in facing up to these two challenges.

The Nordic forestry ministers note that viable forests, which generate raw materials and services for industry, a diversity of plants and animals, as well as a place for recreation, are a prerequisite for competitive forestry in the Nordic Region. In addition, the forestry ministers:

I. want, taking into account the forest's biological diversity and leisure potential, to work towards increased sustainable biomass production in the Nordic Region's forests, which is an important measure in counteracting climate change and reducing the competition between cultivation of biomass for bio-energy and for other purposes

II. place great weight on protection and care of forests with the aim of safeguarding the eco-system, bio-diversity and the groundwater, as well as counteracting erosion and protecting watercourses

III. note that afforestation ought to be increased and that forest management and the use of wood be developed on the basis of the starting point in the joint European guidelines in order to create viable forests and thereby counteract the negative consequences of climate change

IV. place weight on the forestry sector participating actively and constructively in the discussion of the forest's role in a climate context in order to facilitate the optimum use of the forest's potential and ensure that any measures taken are based on sustainable forest management 
$V . \quad$ wish to strengthen co-operation and the sharing of experiences within the Nordic Region, so that Nordic forest users have access to and knowledge about how they can, in a way that is efficient in terms of resources, take care of the forest's water and how they can adapt forest management as a consequence of climate changes

VI. stress the importance of tree-breeding, including genetic adaptation to climate change and the adoption of new measures whenever necessary

VII. place great weight on the forest's local and regional importance for healthy economic development, e.g. income from tourism and hunting, which is a prerequisite for active forest management and thereby a further development of the forest's importance in a climate and water-management context

VIII. support the idea that forests which aim, for example, to protect against erosion or preserve biological diversity or are planted to rehabilitate eroded fields, should also be capable of being used for timber production, as long as this contributes to looking after the forests' ecological, social and economic values

IX. note that high-quality research and innovation is required in all of these areas, and that closer Nordic co-operation is required for Nordic forestry research to remain at the forefront of forest research in an international context in the future as well. ${ }^{1}$

Following the SD, an ad-hoc committe was appointed by the EK-FJLSskog to give recommendations on how to implement and follow up on the declaration. The appointed members of the ad-hoc group were Jón Geir Pétursson, The Icelandic Ministry for the Environment and Natural Resources, chairman, Pernille Karlog, Minstry of the Environment, Denmark, Sune Haga, SamNordiskSkovforskning, Finland, Birgitta Naumburg, Ministry of Agriculture, Sweden, Tore Skrøppa, Norwegian Forest and Landscape Institute, and Danfríður Skarphéðisdóttir, Ministry of the Environment, Iceland. In addition to the group Mikael Sandvik of the forest authorities in the Åland Islands was consulted. Secretary of the group was Hrefna Jóhannesdóttir project coordinator of CSO (agriculture and forestry) and Mr Porbergur Hjalti Jónsson, forests scientist, at Icelandic Forest Research Mógilsá was appointed to compile relevant

\footnotetext{
1 The Nordic Council of Ministers - The Ministers of Forestry. Ministerial declaration adopted in Selfoss, Iceland 19th August 2008.
} 
information on issues of the Selfoss declaration, collect background data and assist in the analyses.

The committee identified the key issues presented in the SD and mapped the current state of policy, law, regulation and research relevant to the SD within and among the Nordic countries. Based on that, the committee sent a questionnaire to the signatory countries and asked for further clarification on the current state, using the response to make and publish a report with policy recommendations on how to implement the commitments of the SD: Recommendations for follow-up of the Selfossdeclaration on forests, climate and water (RSD). ${ }^{2}$ The recommendations were two-fold; policy recommendations to the Nordic co-operation structures (Table 1) and more direct measures that included different activities to be undertaken by different Nordic actors (Table 2). The adhoc committee proposed that three organs within Nordic co-operation; SNS, NordGen Forest and the EK-FJLS-skog, initiate and motivate the implementation of the Selfoss declaration. In addition the RSD included background information for the proposed recommendations and an indepth analysis of the challenges presented in SD. The full report can be downloaded from the NMR website. ${ }^{3}$

2 Implementing the Selfoss Declaration - Recommendations to Nordic forestry. TemaNord 2010:554. Nordic Council of Ministers, 2010, p. 58.

${ }^{3}$ http://www.nord en.org/is/utgafa/utgefid-efni/2010-554/at_download/publicationfile 
Table 1. Policy priorities recommended in the RSD to secure the implementation of SD ${ }^{4}$ Policy recommendations Directed to:

The Nordic Forest Research Cooperation Committee (SNS) continues to bring together the Nordic competence within the scope of the declaration. A preferable way of seeing that materialised is to facilitate the activities of specific Centres of Advanced Research (CAR) within the field of forests and climate, and water respectively

SNS promotes cooperation with the Nordic Energy Research (NER) and the Nordic Joint Committee for Agricultural Research

The ad-hoc group welcomes the recent initiative to connect SNS with EFI and urges that the collaboration will focus on projects that include interrelations of forest to water and climate

NordGen Forest will gain a stronger position within NordGen, as the need for adaptation of forest trees to climate change is inevitable in coming years

Given the importance of the Nordic forests for the climate commitments of the Nordic countries, there should be a strengthened collaboration between CSO-Environment and CSO-Forestry on climate change issues. It is the task of CSO-Environment to develop Nordic climate change strategies and contribute to the climate change negotiation

It is important that NMR does not further reduce already dwindling budgets to SNS and NordGen Forest, but rather increases the budgets so that SNS and NordGen can coordinate high-quality Nordic forest research in networks and projects

SNS board

The ad-hoc group suggests SNS and NordGen Forest to seek collaboration with the different inter-sectorial strategies within the Nordic cooperation on issues related to forests, climate change and water. This will facilitate implementation of the resoulutions of the Selfoss declaration. The group emphasises the following strategies: Sustainable development, The Baltic Sea, Globaliseringsinitiative, Neighbours both in East and West (perhaps other strategies)

SNS board

SNS board

NordGen board

EK-M and EKFJLS skog

EK-SAM and EKFJLS skog

EK-FJLS skog, the boards of NordGen and SNS

Table 2. Recommendations for direct measeures table from the RSD ${ }^{5}$

\begin{tabular}{|c|c|c|c|}
\hline Measure & $\begin{array}{l}\text { Resolution } \\
\text { point }\end{array}$ & Proposed activity & Brief description \\
\hline 1 & 1,2 and 3 & Workshop & $\begin{array}{l}\text { Focusing on how the Nordic countries can increase } \\
\text { sustainable forest biomass production }\end{array}$ \\
\hline 2 & 5 & Desk study & $\begin{array}{l}\text { How Nordic forest management strategies have to } \\
\text { evolve to adapt to climate change }\end{array}$ \\
\hline 3 & 5 & Seminar & $\begin{array}{l}\text { The EU water framework directive and Nordic } \\
\text { forestry, including good practices examples of } \\
\text { integrated water management in the forest } \\
\text { landscape }\end{array}$ \\
\hline 4 & 4 & Web portal & $\begin{array}{l}\text { To collect and disseminate research results rele- } \\
\text { vant to the Selfoss declaration }\end{array}$ \\
\hline 5 & 9 & $\begin{array}{l}\text { Promotion and publica- } \\
\text { tion }\end{array}$ & $\begin{array}{l}\text { Promote and inform about the importance of } \\
\text { forests for climate and water }\end{array}$ \\
\hline
\end{tabular}

${ }^{4}$ Implementing the Selfoss Declaration - Recommendations to Nordic forestry. TemaNord 2010:554. Nordic Council of Ministers, 2010, p. 8-9.

5 Table 2,1 from Implementing the Selfoss Declaration - Recommendations to Nordic forestry. TemaNord 2010:554. Nordic Council of Ministers, 2010, p. 10-11. 


\begin{tabular}{|c|c|c|c|}
\hline Measure & $\begin{array}{l}\text { Resolution } \\
\text { point }\end{array}$ & Proposed activity & Brief description \\
\hline 6 & 3 and 4 & $\begin{array}{l}\text { Workshop and publicati- } \\
\text { on }\end{array}$ & $\begin{array}{l}\text { Advancing the potential of the Nordic forests to } \\
\text { mitigate climate }\end{array}$ \\
\hline 7 & 3 & Desk study & $\begin{array}{l}\text { Analyses and publication of forest management } \\
\text { strategies to increase climate change mitigation in } \\
\text { the different types of forests found in the Nordic } \\
\text { countries }\end{array}$ \\
\hline 8 & 3 & Desk study & $\begin{array}{l}\text { Study and recommendations on how the pan- } \\
\text { European guidelines for afforesta- } \\
\text { tion/reforestation could be applied in the Nordic } \\
\text { countries }\end{array}$ \\
\hline 9 & 3 & Workshop & $\begin{array}{l}\text { Workshop on how the Nordic wood in permanent } \\
\text { constructions can be promoted }\end{array}$ \\
\hline 10 & 8 & Desk study & $\begin{array}{l}\text { Good practice examples of forest restoration of } \\
\text { degraded areas }\end{array}$ \\
\hline 11 & 8 & Workshop & $\begin{array}{l}\text { Protection forestry including new alternative forms } \\
\text { of forest protection (e.g. the METSO experience) }\end{array}$ \\
\hline 12 & 6 & Project, field trials & $\begin{array}{l}\text { Develop reproductive materials for future climatic } \\
\text { conditions }\end{array}$ \\
\hline 13 & 6 & $\begin{array}{l}\text { Collaborations and } \\
\text { exchange }\end{array}$ & $\begin{array}{l}\text { Increased cooperation in Nordic forest tree } \\
\text { breeding and breeding research }\end{array}$ \\
\hline 14 & 6 & Desk study & $\begin{array}{l}\text { Monitor possible changes in genetic diversity of } \\
\text { forest tree species under changing climate } \\
\text { conditions }\end{array}$ \\
\hline 15 & 2 & Desk study & $\begin{array}{l}\text { Collecting good examples of how biodiversity } \\
\text { conservation is integrated into forest policy and } \\
\text { practice in the Nordic countries }\end{array}$ \\
\hline 16 & 2 and 1 & $\begin{array}{l}\text { Desk study - contribute } \\
\text { to measure } 1 .\end{array}$ & $\begin{array}{l}\text { The importance of dead and decaying wood for } \\
\text { forest biodiversity }\end{array}$ \\
\hline 17 & 2,3 and 6 & Desk study & Risk assessment of new forest tree species \\
\hline 18 & 2 & Information system & $\begin{array}{l}\text { Risk analyses and establishment of a system to } \\
\text { address potential pathogens in Nordic forestry as a } \\
\text { result of climate change }\end{array}$ \\
\hline 19 & 2,3 and 7 & Desk study & $\begin{array}{l}\text { Collect and analyze examples of afforestation/tree } \\
\text { planting projects in the Nordic countries where } \\
\text { the benefits from carbon finance have been one of } \\
\text { the driving forces }\end{array}$ \\
\hline 20 & 7 & Conference & The multiple and local value of Nordic forestry \\
\hline
\end{tabular}




\section{The Achievements of Selfoss Declaration}

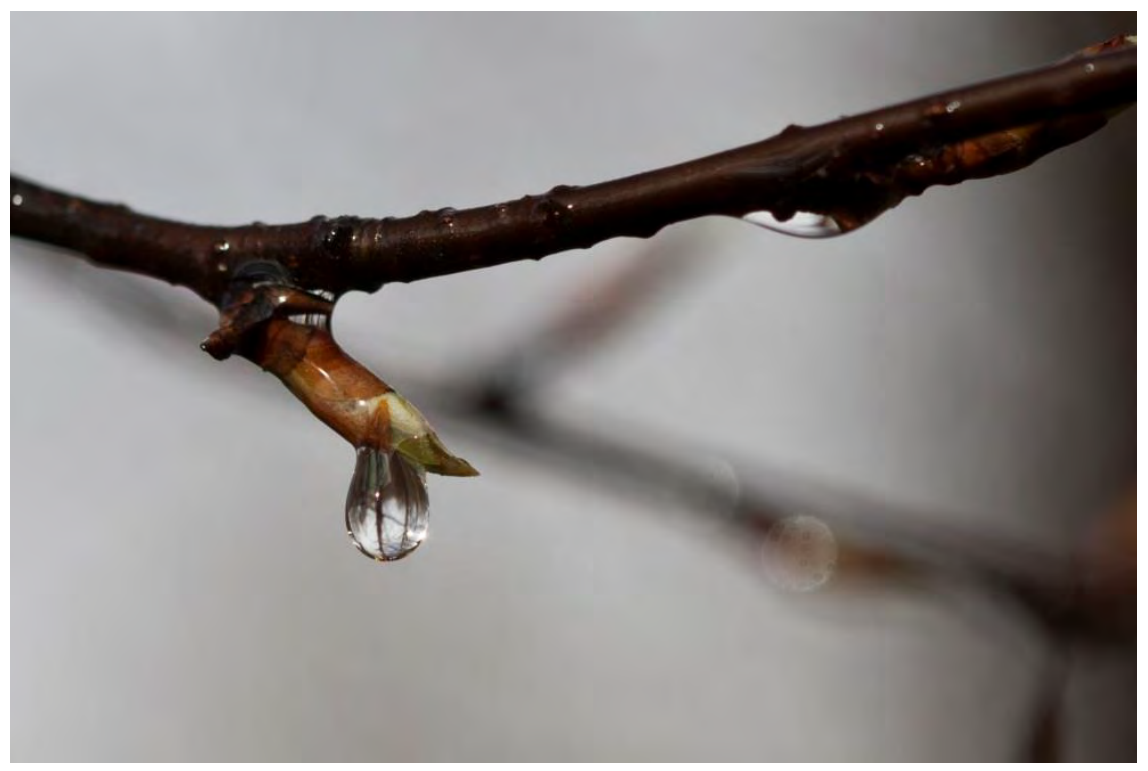

This report aims to reflect on the achievements of the SD and the RSD report. The question is; did the forestry sector focus on the resolutions that the forestry ministers acknowledged in the SD and furthermore, how did it affect the forestry sector in the Nordic countries?

In order to get an overview of the implementation of the Selfoss Declaration, a questionare was sent to the SNS secreteriat, NordGen Forest and members of EK-FJLS skog, examinating which of the proposed activities took place, which countries participated and what output had already been published or was expected from individual acitvities. The offices were also asked to reflect on the overall usefulness of the Selfoss declaration work and the general impact. The questions are found in Appendix 1. Furthermore, additional data from several different web-sites were used to get a more comprehensive view of the activities that took place. 
The report starts with a short reflection on the policy recommendations from the RSD report, followed by a short overview of activities that were performed from 2008 with SNS, NordGen Forest and EK-FJLS skog support. Each activity is then described, according to information from the questionnaire and available websites. Finally, the effect and importance of the SD on the forest sector in the Nordic countries is discussed andrecommendations made for future policy-making on forestry on the Nordic level. 


\section{Reflection on Measures, Activities and their Impact}

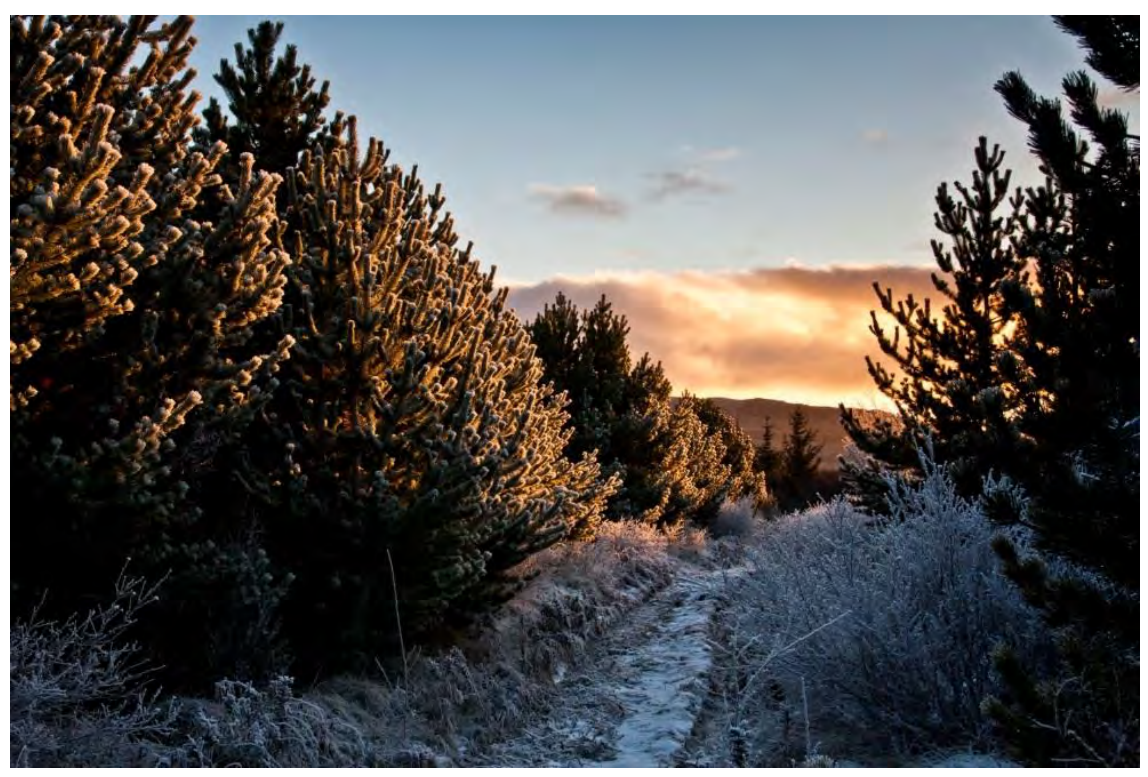

As mentioned earlier, the RSD contained both policy recommendations (Table 1) and more precise actions (Table 2), based on the priorities that the Nordic Forestry Ministers highlighted in the SD.

\subsection{Policy recommendations}

Policy recommendations, or policy priorities, were directed to different NMR offices and boards to ensure the implementation of the SD (table 1).

Several Centres of Advanced Research (CAR) actions have been established within SNS where the focus is within the scope of the SD. These actions include CAR-ES, AdapCar and OSCAR2, that have held numerous workshops, promoted collaboration on new research and papers within the field of climate change and its effect on forest, water and genetic adaptation of boreal forest trees. 
SNS has promoted cooperation and collaboration within the Nordic countries in multiple ways, and the collaboration between SNS and NER resulted in a substantial grant from SNS to NER. The activities involve many researchers from the SNS networks and are coordinated by Palle Madsen at the Copenhagen University. There are also several SNS/EFI networks that include interrelations of actions between forest, water and climate, some of which have led to research projects, such as the Sino-Swedish Mercury Management Research Framework that recently received a 5-year funding, starting in 2014.

Increased cooperation between inter-sectorial strategies within the Nordic and Baltic cooperation can for example be seen in the high number of activities that include participants from one or more Nordic and Baltic countries.

Following the SD, the budget of NordGen Forest has increased about $35 \%$. This increase has been used to strengthen core activities, such as thematic days, conferences and dissemination work. The same cannot be said about theSNS-budget. In 2010 its budget got reduced as the general budget of NMR was reduced. The relative proportion of SNS's budget to NMR's has however stayed the same.

\subsection{Activities}

In the RSD report, twenty different measures were recommended to cover the nine resolutions mentioned by the ministers in the SD. In most cases, no time limits were suggested for executing the measures, nor were they prioritized. Based on information from SNS and NordGen Forest, more than 20 activities took place within the recommended measures in the RSD report (Table 3) during the years 20082013, with some still on-going. The majority of the activities were research projects and networks, but others included desk studies, workshops, conferences, and web sites. One activity, AdapCar, Centre for Advanced Reserarch in forest genetics, breeding and regeneration for adapting and mitigating climate change, is listed in more than one resolution, highlighting the fact that the resolutions' points in the SD are interwined to some degree.

Numbers of participants in the activities are variable, from one or few participants in desk studies to larger networks and conferences. Participants come from all the Nordic countries, with involvement from the Baltic countries, Russia, Germany, UK and other countries in some activities. 
The outcomes of these activities are variable and with diverse accessability. For most finished desk studies, research projects and networks, final reports can be found online and in many cases papers in peer-reviewed journals are also available. It can be more difficult to find information on workshops and conferences that have already passed. In many cases only the program is available, but no summary on the outcome of the workshop/conference. Exceptions to this are conferences organized by NordGen Forest, which have most of the presentations as pdf files and short summaries on their website. This increases by far the usefulness of the conferences/workshops.

Even though it is difficult to measure the effect of the activities on the forestry sector or other aspects in the Nordic countries, it was a general opinion that the SD initiated many activities and incisive actions in organizing forest research cooperation across national boundaries at the Nordic level. Initiation of new networks and continuation of older ones have facilitated exchange of ideas and strengthened the co-operation of scientists within specific fields in the Nordic countries. It also provided outreach to stakeholders and policy makers, for example on the development of reproductive seed material suitable for future climates, making procedures for ex situ conservation of forest seed samples at Svalbard Global Seed Vault and reviewed a model for risk assessment of introduced species. 


\section{Implementation of Different Activities}

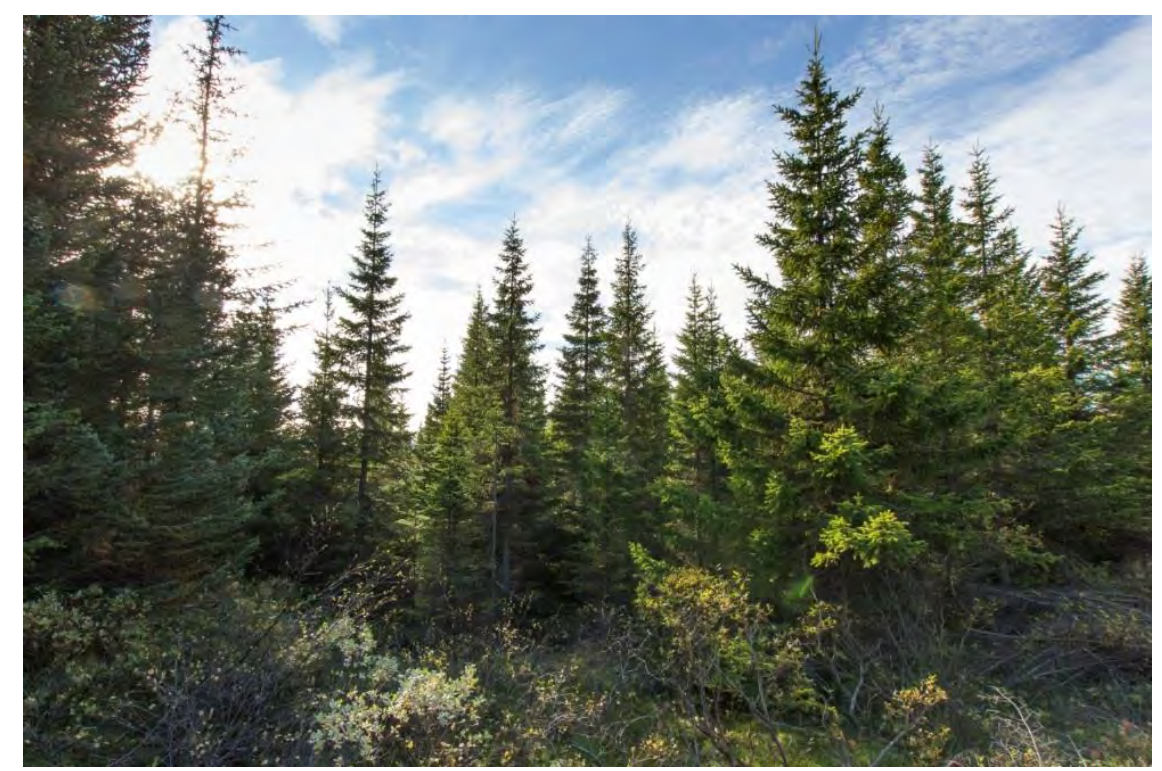

The individual activities are described based on information from SNS, NordGen Forest, EK-FJLS and online sources. The activities are grouped by resolution points from the SD, which are shown at the beginning at each sub-chapter. 
Table 3. Brief description of activites carried out in relation to the resolution points in the SD

\begin{tabular}{|c|c|c|}
\hline $\begin{array}{l}\text { Resolution } \\
\text { point }\end{array}$ & Brief description of activity & $\begin{array}{l}\text { Measure in } \\
\text { RSD report }\end{array}$ \\
\hline \multirow[t]{4}{*}{ I } & NordGen Forest conference "Sustainable biomass production" & 1 \\
\hline & SNS-118: "Ecological effects of intensive biomass harvesting in the Nordic and Baltic countries" & 1 \\
\hline & "ENERWOODS", financed by Nordic Energy Research under the programme for Sustainable Energy Systems 2050 & \\
\hline & Facts and Figures of the EFINORD Forest Sector & \\
\hline \multirow[t]{5}{*}{$\|$} & SNS-CAR: "CAR-ES Centre of Advanced Research on Environmental Services from Nordic forest ecosystem" & 19 \\
\hline & SNS-110: "Leaching of carbon, nitrogen and phosphorus from forest land in the Nordic and Baltic countries" & 19 \\
\hline & $\begin{array}{l}\text { SNS-113: "Risk assessment and establishment of a system to address potential pathogens in Nordic forestry as a } \\
\text { result of climate change" }\end{array}$ & 18 \\
\hline & SNS-117: "Preventive and restorative measures to reduce damage on forests - Phythoptora diseases in focus" & 18 \\
\hline & SNS network N 2012-04: "Phytophthora-diseases of deciduous forest trees in Nordic and North-European regions" & 18 \\
\hline \multirow[t]{6}{*}{ III } & SNS-114: "Risk assessment of new forest tree species" & 7 \\
\hline & SNS-112: "Improving market communication of wood products' environmental values" & \\
\hline & $\begin{array}{l}\text { SNS-CAR: "AdapCAR Centre for Advanced Research in forest genetics, breeding, and regeneration for adapting } \\
\text { mitigating climate change" }\end{array}$ & 7 \\
\hline & $\begin{array}{l}\text { EUSBSR-projects: } \\
\text { Project 1. Cooperation in breeding of Norway spruce (2011-2012). Its purpose is to promote active use and conser- } \\
\text { vation of genetic resources of selected tree species, for increased flexibility with regard to sustainable forest man- } \\
\text { agement and adaptation to climate change. }\end{array}$ & 7 \\
\hline & Project 2. Evolutionary genetic pockets for broadleaved tree species (pilot project) & \\
\hline & NordGen Forest conference "Regeneration in afforestation landscapes" & \\
\hline IV & Web portal "NBforest - research-based information on Nordic and Baltic forests and forestry" & 4 \\
\hline \multirow[t]{2}{*}{ V } & $\begin{array}{l}\text { SNS-CAR: "AdapCAR Centre for Advanced Research in forest genetics, breeding, and regeneration for adapting } \\
\text { mitigating climate change" }\end{array}$ & 2 \\
\hline & Workshop: "Climate change and forestry in northern Europe" & \\
\hline \multirow[t]{6}{*}{$\mathrm{VI}$} & $\begin{array}{l}\text { Desk study: Searching for appropriate legislation regulating the access and exclusive rights to forest genetic re- } \\
\text { sources in the Nordic region }\end{array}$ & \\
\hline & NordGen Forest meetings: Increased cooperation in Nordic forest tree breeding and breeding research & 13 \\
\hline & Desk Study: "Monitor possible changes in genetic diversity of forest tree species under changing climate" & 14 \\
\hline & SNS-114: "Risk assessment the new forest tree species" & 17 \\
\hline & $\begin{array}{l}\text { SNS-CAR: "AdapCAR Centre for Advanced Research in forest genetics, breeding, and regeneration for adapting } \\
\text { mitigating climate change" }\end{array}$ & 12 and 13 \\
\hline & NordGen Forest conference: "Northern Forest in a Changing Climate" & \\
\hline VII & SNS-CAR: “CARe-FOR-US II. Nordic-Baltic Centre of Advanced Research on Forestry Serving Urbanised Societies” & \\
\hline IIX & Workshop: "Afforestation to protect land, restore degraded land and sequester carbon". - Hvolsvollur conference & 11 \\
\hline \multirow[t]{2}{*}{ IX } & $\begin{array}{l}\text { EUSBSR-project: "Forestry and Water network, within the project Forestry and Water Protection under the EU } \\
\text { Strategy for the Baltic Sea Region" }\end{array}$ & 5 \\
\hline & SNS network: "Nordic Forest Water Mercury Network" (NorForM) & 5 \\
\hline
\end{tabular}




\subsection{Point I}

The forestry ministers want, taking into account the forest's biological diversity and leisure potential, to work towards increased sustainable biomass production in the Nordic Region's forests, which is an important measure in counteracting climate changes and reducing the competition between cultivation of biomass for bio-energy and for other purposes.

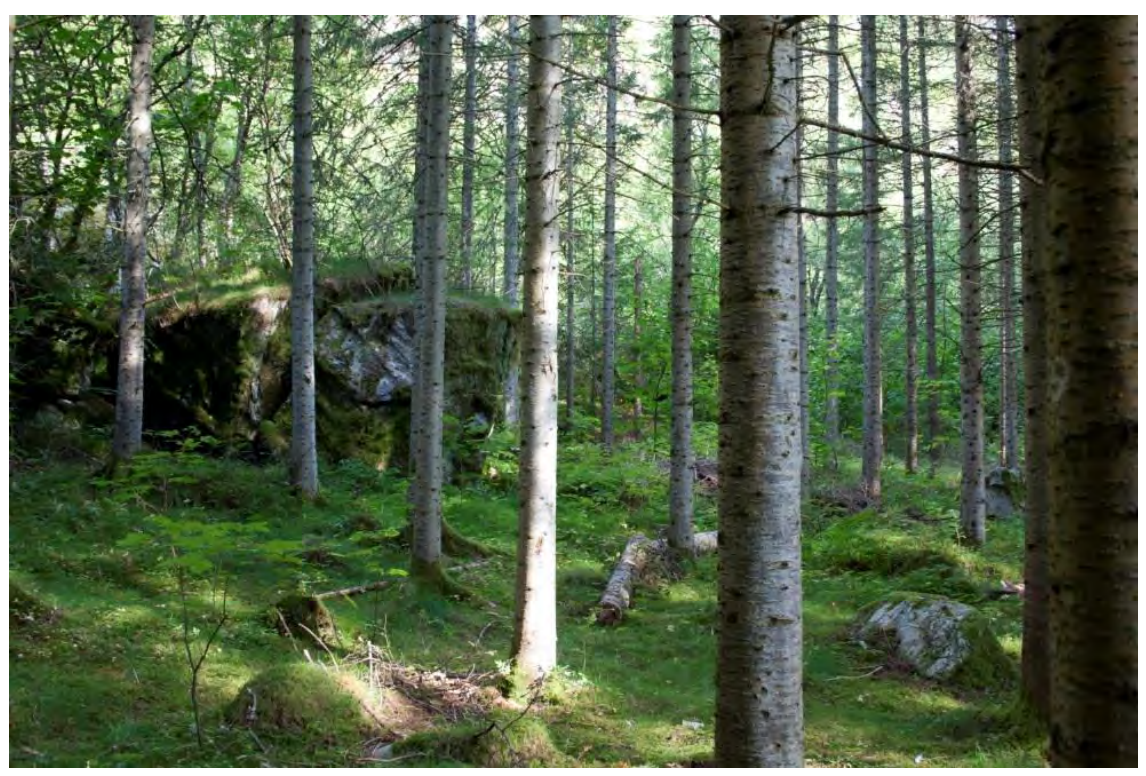

\subsubsection{NordGen Forest conference: Sustainable biomass production}

- Activity: NordGen Forest conference where Nordic researchers and managers presented current and future perspectives for bioenergy, discussing f.ex. biomass resources in the Nordic countries, conversion technologies, markets and economy.

- Year: 2011

- Responsible actor: Gunnar Friis Proschowsky, Naturstyrelsen i Danmark.

- Output: Programme and presentations can be downloaded from the NordGen website. ${ }^{6}$

\footnotetext{
${ }^{6}$ http://www.nordgen.org/index.php/en/Forest/Innehaall/Conferences/Previous-conferences/NordGenForest-Conferences
} 
- Website: www.nordgen.org/index.php/en/content/view/ full/1893

- Measure in RSD: 1.

\subsubsection{SNS-Research project (SNS-118): Ecological effects of intensive biomass harvesting in the Nordic and Baltic countries}

- Activity: Research project with the aim to build a Nordic-Baltic database and use it for doing a metadata-analysis in order to quantify the effects of forest harvesting on soil nutrient, soil carbon, water and biodiversity.

- Year: 2013-2014.

- Responsible actors: Nicholas Clarke, Skog og Landskap, Norway

- Participating countries: Norway, Denmark, Finland, Iceland, Sweden, Lithuania, Latvia.

- Expected output in 2014: Online Nordic-Baltic database with relevant experiments and overview of relevant data, meetings and a report. A review paper about the results of the metadata-analysis.

- Website: www.nordicforestresearch.org/sns-research/researchprojects/ecological-effects-of/

- Measure in RSD: 1.

\subsubsection{Research project: ENERWOODS}

- Activity: The research project, financed by Nordic Energy Research, aims to strengthen the role of Nordic forestry as a significant contributor to the development of renewable energy systems. The project aims to link end-users and the forest sector by giving high priority to end-user involvement and showing that forests are "the green oilfields of the future."

- Year: 2011-2015.

- Responsible actor: Palle Madsen, Project Manager, University of Copenhagen, pam@life.ku.dk

- Participating countries: Sweden, Finland, Denmark, Norway

- Output: Several project meetings; Establishment of demonstration areas that demonstrate highly productive silvicultural systems with fast growing conifers as well as broadleaves; Thematic Days, "Road Shows" and Excursions in participating countries.

- Website: www.enerwoods.dk 


\subsubsection{Facts and figures of the EFINORD forest sector}

- Activity: Research project, financed by the Nordic Council of Ministers, compiled facts concerning forestry and forests in north European countries, to describe and discuss prerequisites for forestry and possibilities for intensive forest management and increased increment of forests in short and long term.

- Year: 2011-2013.

- Responsible actors: Mika Mustonen, North European regional office of European Forest institute EFINORD, Tomas Lundmark, the Swedish University of Agricultural Sciences, Faculty of Forest Sciences.

- Participating countries: 13 north European countries.

- Output: Report on the conditions and prospects for increasing forest yield in northern Europe. ${ }^{7}$

- Website: http://www.efinord.efi.int/portal/projects/ facts_and_figures_of_the_efinord_forest_sector/

${ }^{7}$ Jonsson et al. 2013. Conditions and prospects for increasing forest yield in northern Europe. Working Papers of the Finnish Forest Research Institute 271. Available online:

http://www.metla.fi/julkaisut/workingpapers/2013/mwp271.htm 


\subsection{Point II}

The forestry ministers place great weight on protection and care of forests with the aim of safeguarding the eco-system, bio-diversity and the groundwater, as well as counteracting erosion and protecting watercourses.

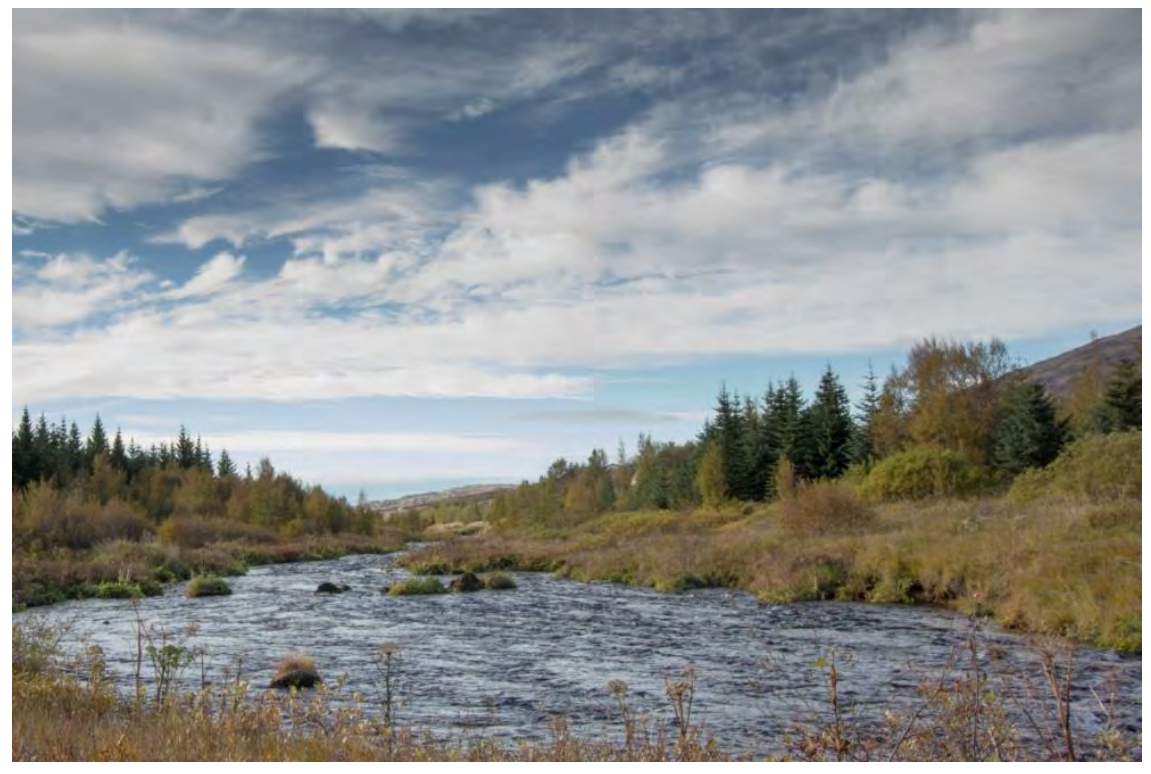

\subsubsection{Network: CAR-ES Centre of Advanced Research on Environmental Services from Nordic forest ecosystems}

- Activity: An open network with the aim of providing scientific knowledge on the impacts of forest management and environmental services for decision making within the foresty sector in the Nordic and Baltic countries. This is done by making use of large number of field experiments conducted within the countries, so it will deliver mutual benefits and integrate knowledge about environmental services at a broad scale.

- Year: 2011-2015 (continued from earlier CAR; 2005-2010).

- Responsible actor: Inge Stupak, Department of Geosciences and Natural Resource Management, University of Copenhagen, Denmark.

- Participating countries: Sweden, Finland, Denmark, Iceland, Norway, Lithuania, and Latvia.

- Output: A long list of scientific papers, two-three meetings each year in 2011, 2012, and 2013.

- Website: www.nordicforestresearch.org/car-es/

- Measure in RSD: 19. 


\subsubsection{SNS-Research project (SNS-110): Leaching of carbon, nitrogen and phosphorus from forest land in the Nordic and Baltic countries}

- Activity: Metadatabase research.

- Year: 2011-2013.

- Responsible actor: Lars Högbom, Skogforsk, Sweden.

- Participating countries: Sweden, Finland, Iceland, Latvia, Lithuania, and Norway.

- Output: A prototype version of a metadatabase is completed. In 2014 the metadatabase will be quality checked, and summaries will be published. NB Forest Policy and Research Briefs, published January 2014.

- Any further work using this activity's outcome: Work is ongoing to expand the geographic coverage of the database. Efforts are being made to identify additional sites elsewhere in the Baltic Sea catchment area. After quality control checks are complete, further analyses will be performed for a better understanding of the relationship between forest lands and Baltic Sea nutrient problems.

- Website: www.nordicforestresearch.org/sns-research/researchprojects/leaching-of-carbon-nitrogen-and-phosporus-from-forestland-in-the-nordic-and-baltic-countries/

- Measure in RSD: 19.

\subsubsection{SNS-Research project (SNS-113): Risk assessment and establishment of a system to address potential pathogens in Nordic forestry as a result of climate change}

- Activity: Network.

- Year: 2011-2012.

- Responsible actor: Jan Stenlid, Department of Forest Mycology and Plant Pathology, SLU, Sweden.

- Participating countries: Sweden, Denmark, Finland, Norway, Iceland, Latvia, Estonia, and Lithuania.

- Output: Two meetings were held with expert forest pathologists within the Nordic and Baltic countries that formalized their network and improved cooperation between the experts and other actors 
within the forest sector, such as forestry industry and policy makers. A final report published online ${ }^{8}$ provides a summary of the meetings,evaluates the threat from invasive pathogens, the policy regarding invasive species, and reviews the mechanisms for warning systems for invasive pathogens. Based on that, a framework for detection and monitoring of invasive pathogens and forest pathology extension on invasive pathogens were outlined and recommendations for policy on invasive pathogens formed.

- Websites: www.nordicforestresearch.org/sns-research/researchprojects/previous-research-projects/risk-assessment-andestablishment/ ; www.nordicforestresearch.org/wp-content/ uploads/2012/05/Potential-pathogens-in-Nordic-and-Balticforestry-and-climate-change-2012.pdf

- Measure in RSD: 18.

\subsubsection{SNS-Research project (SNS-117): Preventive and restorative measures to reduce damage on forests - Phythoptora diseases in focus}

- Activity: A study with the aim of assessing the identiy and distribution of Phytphthoras in key pathosystems in Nordic forestry, and to elaborate on protective and restoration methods.

- Year: 2013-2015.

- Responsible actor: Jan Stenlid, Department of Forest Mycology and Plant Pathology, SLU, Sweden.

- Participating countries: Sweden, Finland, Norway, Latvia, and Estonia

- Outcomes: This is an on-going project, but the expected outcomes are a final report, scientific papers, and that the project results in formulation of policy recommendations.

- Measure in RSD: 18.

${ }^{8} \mathrm{http}$ ///www.nordicforestresearch.org/wp-content/uploads/2012/05/Potential-pathogens-in-Nordic-andBaltic-forestry-and-climate-change-2012.pdf 


\subsubsection{SNS network (N 2012-04): Phytophthora-diseases of deciduous forest trees in Nordic and North- European regions}

- Activity: Network - 2 day meeting where the latest information about Phytophthora-diseases in forests was exchanged and the main gaps in current knowledge were identified.

- Year: 2012.

- Responsible actor: Johanna Witzell, SLU, Sweden.

- Participating countries: Sweden, Estonia, Finland, Norway, Germany.

- Output: Network meeting, presentation at SNS-conference, newspaper articles, report to SNS.

- Website: www.nordicforestresearch.org/wp-content/uploads/2011/ 03/SNS-Phytophthora_rapport.pdf

- Measure in RSD: 18. 


\subsection{Point III}

The forestry ministers note that afforestation ought to be increased and that forest management and the use of wood be developed on the basis of the starting point in the joint European guidelines in order to create viable forests and thereby counteract the negative consequences of climate change.

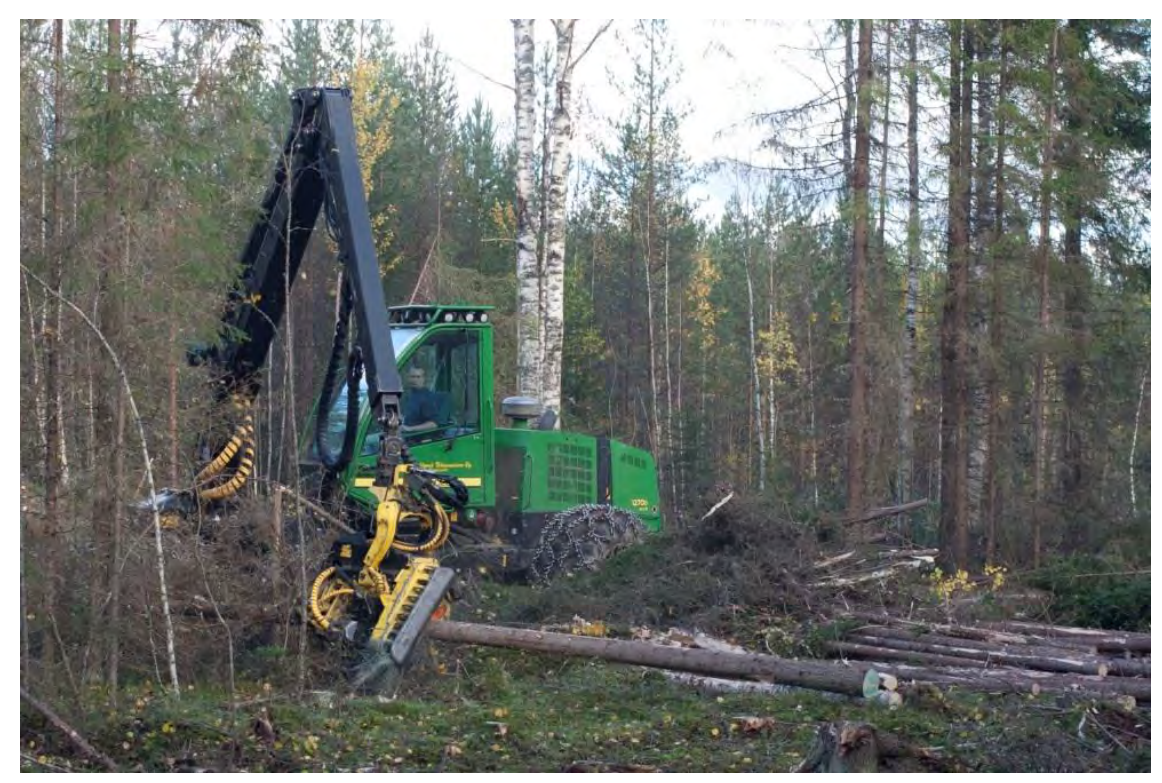

\subsubsection{SNS-Research project (SNS-114): Risk assessment of new forest tree species}

- Activity: Desk study with the main objective to review the state of knowledge on the risk of introduced tree species becoming invasive in the future.

- Year: 2011-2012.

- Responsible actor: Erik Dahl Kjær, Department of Geosciences and Natural Resource Management, University of Copenhagen, Denmark.

- Participating countries: Norway, Sweden and Denmark.

- Output: Report to SNS, available online: Introduction of exotic tree species to meet challenges from climate change in Nordic forestry - a risky business? ${ }^{9}$

${ }^{9}$ Erik Dahl Kjær, Tor Myking, Rita Merete Buttenschøn and Jon Kehlet Hansen (2013). Introduction of exotic tree species to meet challenges from climate change in Nordic forestry - a risky business?

http://www.nordicforestresearch.org/wp-content/uploads/2012/06/Invasive-species_Scientific-report.pdf 
In the report, the effects of climate change on motivation for introducing new species in Baltic/Scandinavian forestry are discussed, the global litterarture on common features of introduced,and invasive species is reviewed, the experience from Denmark with woody species that have become invasive and the Norwegian approach on setting up a systematic method for risk analysis is discussed. In their overall conclusion, the authors point out that the exclusive use of presently native species may not prove to be sustainable long term solution due to the predicted climate change. However, they recommend a cautious approach, to consider the likely effect of a new species and starting with a pilot scale introduction of new species, gaining experience before spreading the species widely. ${ }^{10} \mathrm{~A}$ peer-reviewed article, "The role of exotic tree species in Nordic forestry," has been published in Scandinavian Journal of Forest Research.

- Website: www.nordicforestresearch.org/sns-research/researchprojects/previous-research-projects/risk-assessment-of-new/

- Measure in RSD: 7.

\subsubsection{SNS-Research project (SNS-112): Improving market communication of wood products' environmental values (pilot study)}

- Activity: Pilot study with the aim to provide a basis for improving the market communication of environmental performance of wood products in the Nordic countries, focusing on business-to-business relations. The study combined assessment of relevant literature, with an assessment of the views and opinions of stakeholders in the Nordic wood industry. This project was accepted as one of the EUSBSR implementations under the common EFINORD flagship umbrella.

- Year: 2011-2012.

- Responsible actor: Tarmo Räty, Metla - Finnish Forest Research Institute.

- Participating countries: Finland, Sweden, Norway.

\footnotetext{
${ }^{10} \mathrm{Kjær}$, E.D., Lobo, A. and Myking, T. (2014). The role of exotic tree species in the Nordic forestry. Scandinavian Journal of Forest Research 29: 323-332.
} 
- Output: Final Report to SNS,11 Working Paper of the Finnish Forest Research Institute. 12

- Has the outcome been useful for the forest sector, and if so, how? The project increased both vertical and horizontal coverage of the value chain and provided a more comprehensive picture on the state-of-theart of enverionmental performance measures in the woodworking industry.

- Any further work using this activity's outcome: The research group has discussed a new plan for future studies within the field.

- Website: www.nordicforestresearch.org/sns-research/researchprojects/previous-research-projects/improving-marketcommunication-of-wood-products-environmental-values/

\subsubsection{SNS Network: AdapCAR - Centre for Advanced Research in forest genetics, breeding, and regeneration for adapting and mitigating climate change}

- Activity: SNS Network, with many members from the previous GENECAR group. The overall aim of this network is to support development and implementation of good use and management of forest genetic resources.

- Year: 2011-2015.

- Responsible actor: Erik Dahl Kjær, Department of Geosciences and Natural Resource Management, University of Copenhagen, Denmark.

- Participating countries: Finland, Norway, Sweden, Estonia, Latvia, Iceland, and Denmark.

- Output: Annual meetings were held in 2011, 2012, and 2013. In 2011 the issue was wise exchange of genetic material ("evolutionary pockets") in Copenhagen. In 2012 a Nordic-Baltic conference was held in Riga on the role of tree breeding for quality and adaption. In 2013 the meeting included a workshop on breeding ash for improved resistance against the fungal disease Hymenoscyphus pseudoalbidus and a PhD course in genomics based breeding in forest trees.

\footnotetext{
11 Tarmo Räty (2012). Final report for project no SNS-112 Pilot study: Improving Market communication of wood products' environmental values. http://www.nordicforestresearch.org/wp-content/uploads/ 2012/03/Final-report-for-project-112.pdf

12 Tarmo Räty, Daniel Lindqvist, Tuula Nuutinen, Anders Q. Nyrud, Sini Perttula, Maria Riala, Anders Roos, Lars G. F. Tellnes, Anne Toppinen and Lei Wang (2012). Communicating the Environmental Performance of Wood Products. P. 71. http://www.metla.fi/julkaisut/workingpapers/2012/mwp230.pdf
} 
Development of new seed sources for resistant trees is underway in both Sweden and Denmark and an information tool box for wise seed transfer is being developed.13 The activities have facilitated cooperation and exchange of ideas. A review paper on the historic and likely future role of exotics in Nordic forestry has been developed for publication in 2014 with Erik Dahl Kjær as PI, but based on cooperation with Nordic partners. A scientific publication on development of "evolutionary pockets" is being developed for international publication in 2014 with Jon Kehlet Hansen from the University of Copenhagen as PI based on cooperation with European partners.Footnote: 13 Eric Dahl Kjær and Jon Kehlet Hansen (2012) New forest tree species and gene pools in Nordic Forestry? Presentation at 40 year jubilee conference. http://www.nordicforestresearch.org/wp-content/uploads/ 2012/07/6_Kjaer_SNS_40.pdf

- Has the outcome been useful for the forest sector, and if so, how? The issue of development of new seed sources with resistance to ash dieback has been discussed with stakeholders in forestry. The role of increased use of exotics in future forestry has also been discussed at several meetings and in several contexts.

- Any further work using this activity's outcome: Activities on development of reproductive material suitable for future climates continue in all the Nordic countries and is part of operational breeding activities. It is anticipated that the outcome of research on adaptation to new abiotic and biotic conditions will be implemented in the on-going breeding and genetic management activities.

- Website: www.nordicforestresearch.org/adapcar/

- Measure in RSD: 7. 


\subsection{Point IV}

The forestry ministers place weight on the forestry sector participating actively and constructively in the discussion of the forest's role in a climate context in order to facilitate the optimum use of the forest's potential and ensure that any measures taken are based on sustainable forest management.

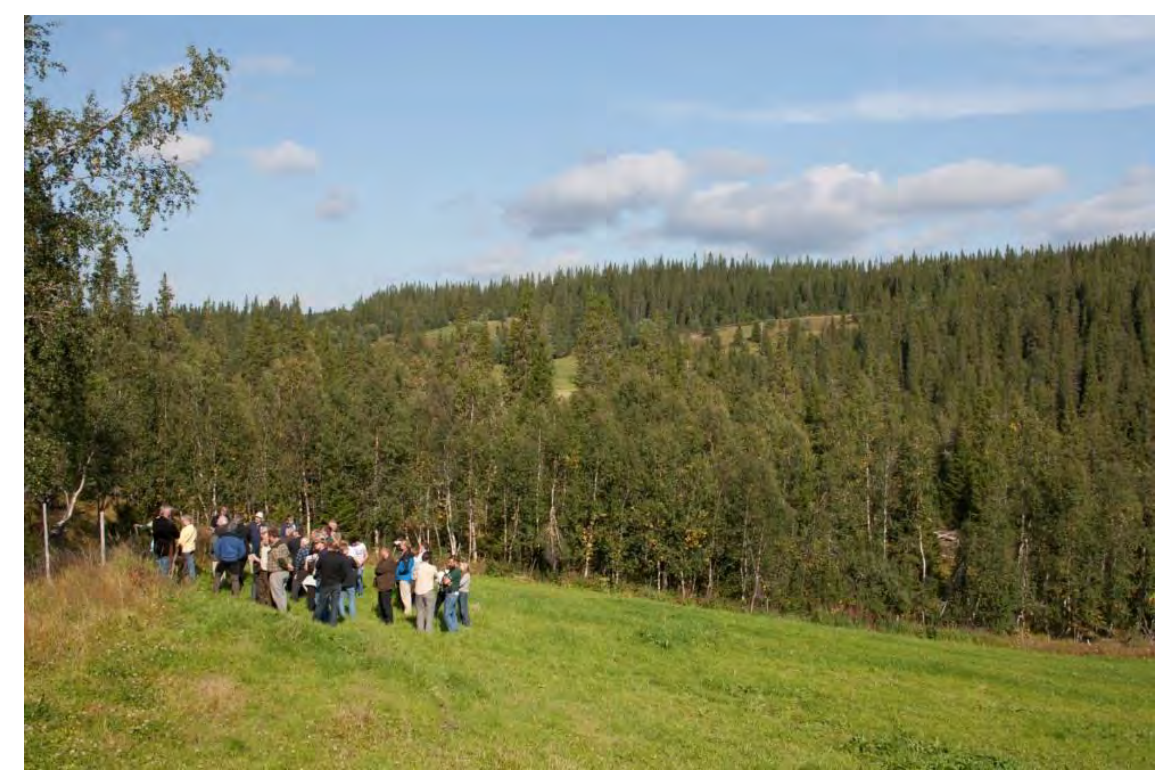

\subsubsection{Web site: NBforest - research-based information on Nordic and Baltic forests and forestry}

- Activity: Web portal.

- Responsible actor: Katrine Hahn Kristensen.

- Participants: Content and visitors from Nordic and Baltic countries.

- Output: The portal was launched in December 2011, and has an average of about 1000 unique visitors per month (as of January 2014).

- Website: www.nbforest.info/

- Measure in RSD: 4. 


\subsection{Point V}

The forestry ministers wish to strengthen co-operation and the sharing of experiences within the Nordic Region, so that Nordic forest users have access to and knowledge about how they can, in a way that is efficient in terms of resources, take care of the forest's water and how they can adapt forest management as a consequence of climate change.

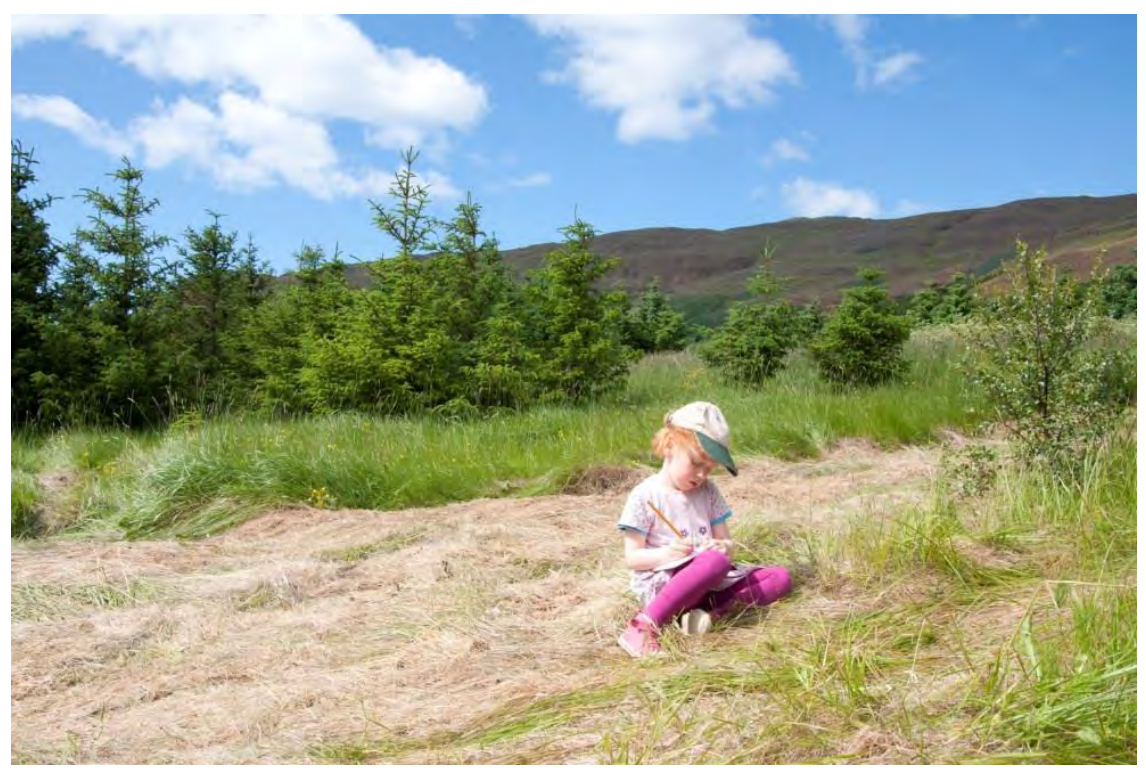

\subsubsection{SNS Network: AdapCAR - Centre for Advanced Research in forest genetics, breeding, and regeneration for adapting mitigating climate change}

- Activity: SNS Network, with many members from the previous GENECAR group. The overall aim of this network is to support development and implementation of good use and management of forest genetic resources.

- Year: 2011-2015.

- Responsible actor: Erik Dahl Kjær, Department of Geosciences and Natural Resource Management, University of Copenhagen, Denmark.

- See 6.3.3 for further information.

- Measure in RSD: 2. 


\subsubsection{Workshop: Climate change and forestry in northern Europe}

- Activity: The workshop was held in Eklunds hof, Uppsala, Sweden and gathered around 50 researchers from Sweden, Finland, Denmark, Estonia, Latvia and Lithuania. The workshop was arranged by EFINORD and Swedish Future Forest program. The presentations illustrated a great variety of implications of climate change in our northern region, based on a new set of climate scenarios recently developed by IPCC. Researchers shared similar thoughts and problems, as well as opportunities and possibilities to adaptation.

- Years: 2013.

- Responsible actors: Johan Bergh, Future Forests program headed by Swedish University of Agricultural Sciences and Mika Mustonen, EFINORD.

- Participating countries: Sweden, Finland, Denmark, Estonia, Latvia and Lithuania.

- Output: Apart from contributing to strengthen a network of researcher, the presentations will be published in a special issue of Silva Fennica. Another workshop is scheduled to be held in 2014 in Finland.

- Website: http://www.efinord.efi.int/portal/projects/ effects_of_climate_change_on_forest/ 


\subsection{Point VI}

The forestry ministers stress the importance of tree-breeding, including genetic adaptation to climate change and the adoption of new measures whenever necessary.

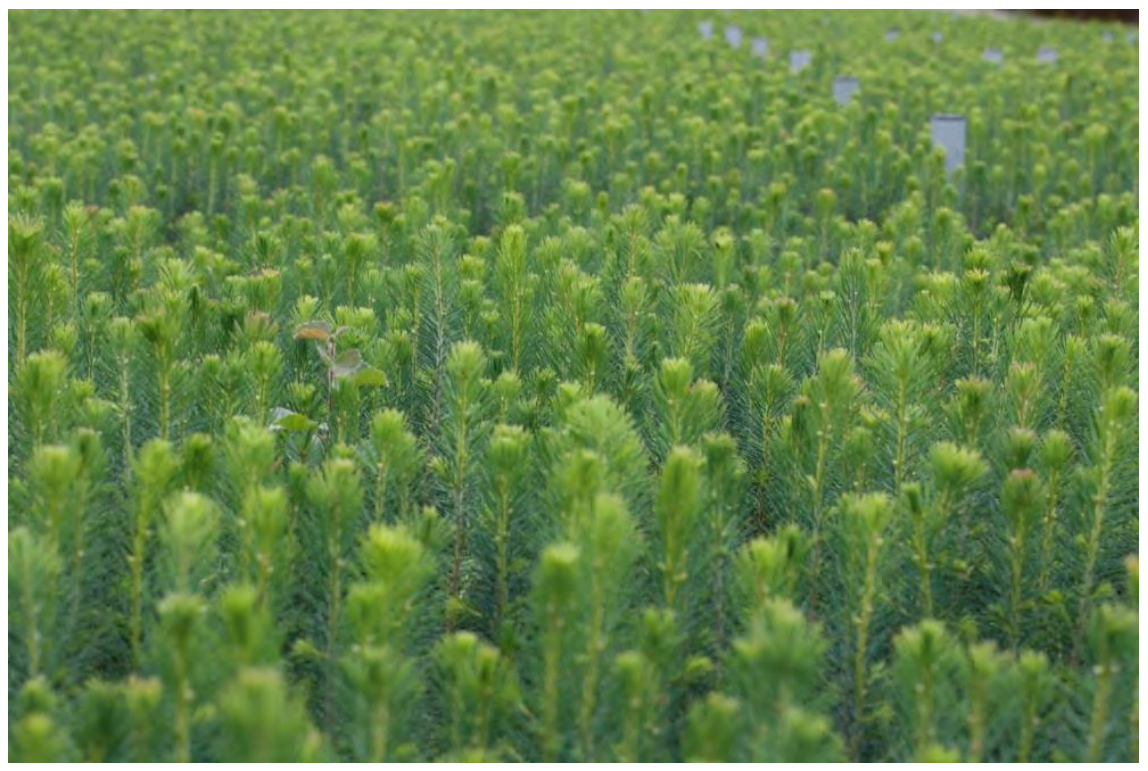

\subsubsection{Desk study: Searching for appropriate legislation regulating the access and exclusive rights to forest genetic resources in the Nordic region.}

- Activity: A desk study, with the aim of describing the present situation regarding access and rigths to forest genetic resources, for example indentifying possible negative effects in international law, investigating the legal status for breeding and breeding material and exploring the relevance of plant breeders' right to the forest sector. The main conclusion of the report published is that no crucial problems were identified regarding ownership, access or exchange of forest genetic resources.

- Year: 2011.

- Responsible actors: Tor Myking, NordGen Forest and Morten Walløe Tvedt, Fridjof Nansen Institute.

- Participating countries: Norway. 
- Output: The report Access and rights to forest genetic resources in the Nordic region is available online. ${ }^{13}$

- Website: www.nordgen.org/ngdoc/forest/Publikasjoner/

Report_ABS_ForestGR_2011.pdf

\subsubsection{Network: Develop reproductive material for future climatic conditions}

- Activity: The topic has been a central part of the cooperation within ADAPCAR - the SNS supported Nordic network for research in forest genetics related to climate change. The overall aim of this network is to support development and implementation of good use and management of forest genetic resources.

- Year: 2011-2015.

- Responsible actor: Erik Dahl Kjær, Department of Geosciences and Natural Resource Management, University of Copenhagen, Denmark.

- See 6.3.3 for further information.

\subsubsection{Increased cooperation in Nordic forest tree breeding and breeding research}

- Activity: Activity has taken place, e.g. at various meetings in the Nordic region and by personal communication among researchers.

- Year: 2010-2014.

- Responsible actor: The forest unit of NordGen has been responsible (NordGen Forest) Contact: Tore Skrøppa.

- Participating countries: Primarily Norway, Sweden and Finland, but also Denmark and the Baltic states (seven countries in total).

- Outcome of the project: The project has contributed to establishing a network among scientists and breeding organisations for better cooperation on breeding of Norway spruce at the Nordic level. Main activities have been exchange of technical staff, participation in project proposals related to breeding across countries, and elaboration of summaries of national breeding strategies. It has also contributed to financing meetings/travels used as a springboard for further Nordic cooperation e.g. on estimation of new deployment

13 Morten Walløe Tvedt (2011). Seeking Appropriate Legislation Regulating Access and Exclusive Rights to Forest Genetic Resources in the Nordic Region. Fridtjof Nansen Institute. FNI Report 9/2011 47p http://www.nordgen.org/ngdoc/forest/Publikasjoner/Report_ABS_ForestGR_2011.pdf 
areas of stand seeds of Norway spruce - and later seed orchard seed. Thus, results are mainly related to strategies and policy.

- Has the outcome been useful for the forest sector, and if so, how? The project has no immediate effect on practical forestry due to the time lag between decisions and results. However, the net result of the project will contribute to making Nordic forestry more robust.

- Any further work using this activity's outcome: The joint interest in cooperation in breeding will continue. Delivery of data for estimation of deployment areas for Norway spruce, facilitated inter-alia by this project, will continue, e.g. as part of Future Forests and separate Norwegian investment in this activity. ${ }^{14}$

- Measure in RSD: 13.

\subsubsection{Desk study: Monitor possible changes in genetic diversity of forest tree species under changing climate.}

- Activity: A desk study with the object to conserve seed samples from representative natural populations for backup storage that can be used for future monitoring of long-term changes in genetic diversity.

- Responsible actor: NordGen Forest, managed by Tore Skrøppa.

- Participating countries: Carried out as a NordGen Forest task, with inputs from all five member countries.

- Outcome: The outcome has been to create a policy document including procedures for ex situ conservation of forest seed samples at Svalbard Global Seed Vault (SGSV), requirements for size of accessions and selection of species (initially Norway spruce and Scots pine). Moreover, The Norwegian Forest Seed Station has been appointed to deal with seed treatment, packing and shipment to SGSV - in close co-operation with NordGen.

- Has the outcome been useful for the forest sector, and if so, how? The outcome has not been useful to the forest sector yet, as the monitoring waits to be initiated and has a timeframe of decades and centuries ahead.

- Measure in RSD: 14.

14 http://www.slu.se/en/collaborative-centres-and-projects/future-forests/ 


\subsubsection{SNS research project (SNS-114): Risk assessment of new forest tree species}

- Activity: Desk study.

- Responsible actor: Erik Dahl Kjær, Department of Geosciences and Natural Resource Management, University of Copenhagen, Denmark.

- Participating countries: Sweden, Denmark and Norway.

- Outcome of the project: The final report has been published online, ${ }^{15} \mathrm{a}$ popular report was published in SNS' News and Views, ${ }^{16}$ a presentation given during the 40 year anniversary of $S N S,{ }^{17}$ a popular article on the method for risk assessment and the case of forest trees published on the NordGen webpage, ${ }^{18}$ and very recently a review paper on introduction of forest tree species in Scandinavia has been submitted to Scandinavian Journal of Forest Research.

- Has the outcome been useful for the forest sector, and if so, how? The results have been widely disseminated, and emphasis has been on experiences with certain cases of invasive woody species, reviewing a model for risk assessment of introduced species, the history and amount of forest tree introductions in the Nordic countries, and production of introduced tree species and their role in the bioeconomy. This broad approach is important for decision-making in forestry in the face of climate change.

- Any further work using this activity's outcome: The results and the process have been very useful for a work package in an EU project (FORGER ${ }^{19}$ ) in which the aim is to review the history and transfer of forest reproductive material in Europe, and where some of the partners in the present desk study were responsible for Scandinavia and Finland. Two scientific publications will result from the collaboration between the present SNS desk study and FORGER.

- Website: www.nordicforestresearch.org/sns-research/researchprojects/previous-research-projects/risk-assessment-of-new/

- Measure in RSD: 17.

\footnotetext{
15 http://www.nordicforestresearch.org/wp-content/uploads/2012/06/Invasive-species_Scientificreport.pdf

16 http://www.nordicforestresearch.org/wp-content/uploads/2013/09/NV_7_2013.pdf

17 http://www.nordicforestresearch.org/wp-content/uploads/2012/07/6_Kjaer_SNS_40.pdf

$18 \mathrm{http}$ //nordgen.org/index.php/en/content/view/full/2179/

19 www.ft7-forger.eu
} 


\subsubsection{SNS Network: AdapCAR - Centre for Advanced Research in forest genetics, breeding, and regeneration for adapting mitigating climate change}

- Activity: SNS Network, with many members from the previous GENECAR group. The overall aim of this network is to support development and implementation of good use and management of forest genetic resources.

- Year: 2011-2015.

- Responsible actor: Erik Dahl Kjær, Department of Geosciences and Natural Resource Management, University of Copenhagen, Denmark.

- See 6.3.3 for further information.

- Measure in RSD: 12 and 13.

\subsubsection{NordGen Forest conference: Northern Forest in a Changing Climate}

- Activity: Conference at Hallormsstaður, East Iceland.

- Year: 2013.

- Responsible actor: NordGen Forest.

- Participating countries: More than 30 participants from all the Nordic countries.

- Output: A short summary on the outcome of the conference ${ }^{20}$ and a part of the presentations can be found in pdf format online. ${ }^{21}$ The summary highlights that changes in climatic conditions will have major impacts on forest growth and health and requires changes in growth rhythm of tree species. Immediate actions that can be applied include shortening rotation age, changes in species planted and using mixture of species/populations. In the long-term a meta-breedingpopulation must be structured in several sub-populations to fit varying conditions and avoid maladaptation.

- Website: www.nordgen.org/index.php/en/Forest/Innehaall/ Conferences/ Previous-conferences/NordGen-Forest-Conferences

\footnotetext{
${ }^{20}$ http://www.nordgen.org/index.php/en/content/view/full/65/

21 http://www.nordgen.org/index.php/en/Forest/Innehaall/Conferences/Previous-conferences/NordGenForest-Conferences
} 


\subsection{Point VII}

The forestry ministers place great weight on the forest's local and regional importance for healthy economic development, e.g. income from tourism and hunting, which is a prerequisite for active forest management and thereby a further development of the forest's importance in a climate and water-management context.

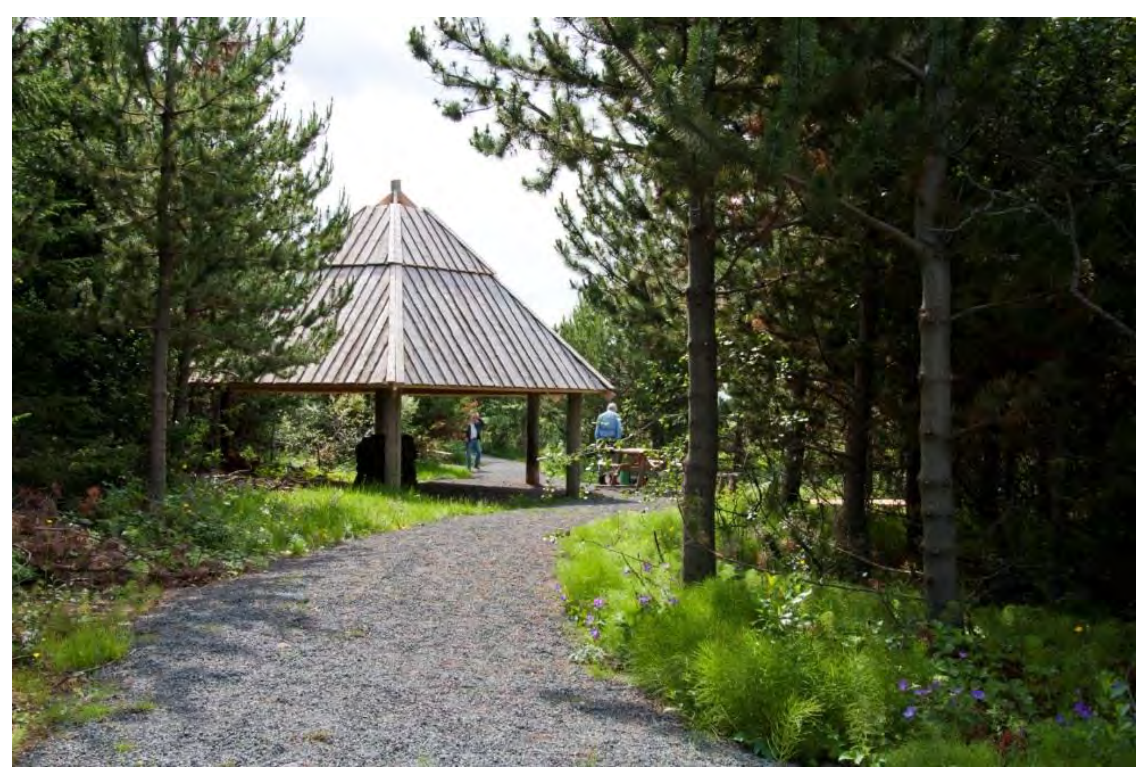

\subsubsection{SNS Network: CARe-FOR-US II: Nordic-Baltic Centre of Advanced Research on Forestry Serving Urbanised Societies}

- Activity: Centre of Advanced Research, Network and Research. This CAR continues from the previus CARe-FOR-US and is based on the research topics indentified there. Four research themes were prioritized; forest governance; nature and human health relations; forest, recreation and tourism; and quality urban forest management. Each theme is coordinated by a senior researcher and a PhD student. Within each theme, several activities have been conducted or are planned, including meetings, $\mathrm{PhD}$ courses, research projects and writing of papers.

- Year: 2011-2015.

- Responsible actor: Dr Anders B. Nielsen. Dept. of Landscape Architecture, Planning and Management, Swedish University of Agricultural Sciences. 
- Participating countries: Denmark, Finland, Iceland, Norway, Sweden, Estonia, Latvia, Lithuania.

- Output: In addition to project meetings, ${ }^{22}$ members from this CAR have contributed to other meetings and conferences, hosted a PhD course and published papers. More papers and reviews are under construction, in addition to a web portal on nature and health.

- Website: www.nordicforestresearch.org/care-for-us2/ 


\subsection{Point IIX}

The forestry ministers support the idea that forests which aim, for example, to protect against erosion or preserve biological diversity or are planted to rehabilitate eroded fields, should also be capable of being used for timber production, as long as this contributes to looking after the forests' ecological, social and economic values.

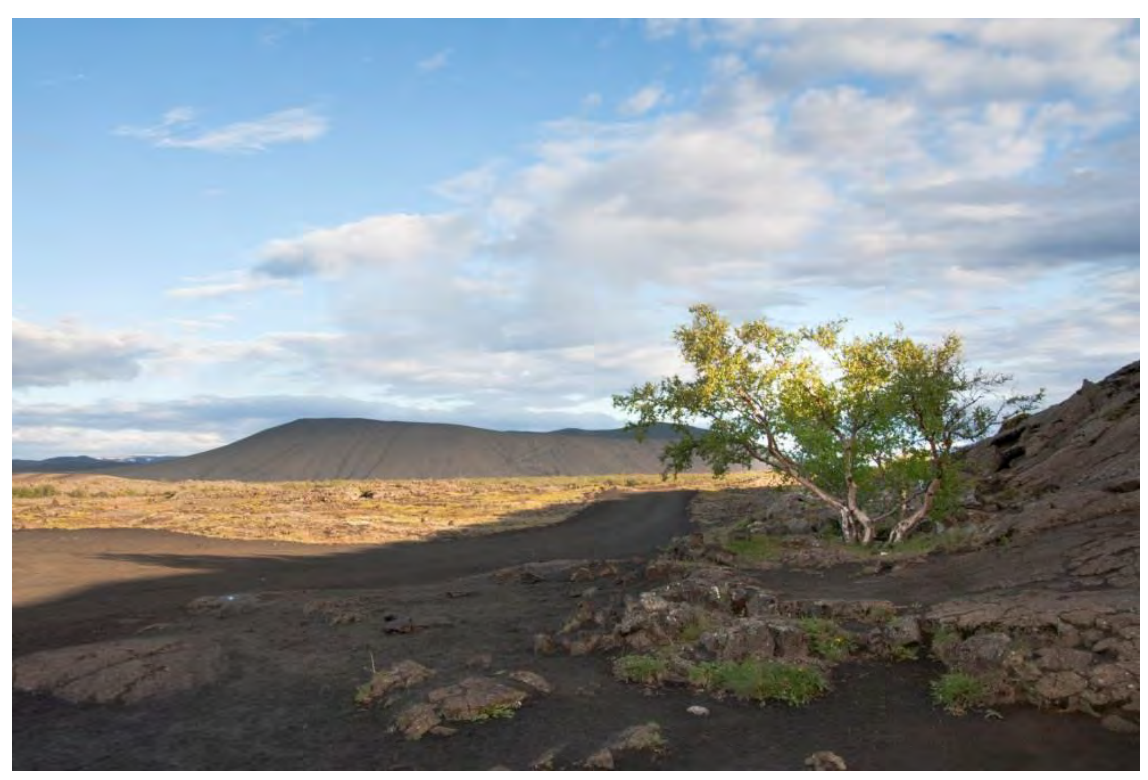

\subsubsection{Workshop: Afforestation to protect land, restore degraded land and sequester carbon}

- Activity: Workshop, with the aim of sharing knowledge on soil erosion, land degradation, desertification and restoration of productive forest functions on degraded land by afforestation.

- Year: 2013.

- Responsible actor: Icelandic Forest Research.

- Participating countries: Iceland, India, Switzerland, Germany, USA, Norway, Denmark. 
- Output: A direct outcome of the workshop was a video about the possibilities of changing desertified land into productive forests, which premiered on the Iceland Forest Service website in conjunction with the International Day of Forests, 21st March, 2014.23

- Websites: www.skogur.is/um-skograekt-rikisins/vidburdir/2013/ 10/23/eventnr/60

${ }^{23}$ http://www.skogur.is/um-skograekt-rikisins/frettir/nr/2097 


\subsection{Point IX}

The forestry ministers note that high-quality research and innovation is required in all of these areas, and that closer Nordic co-operation is required for Nordic forestry research to remain at the forefront of forest research in an international context in the future as well.

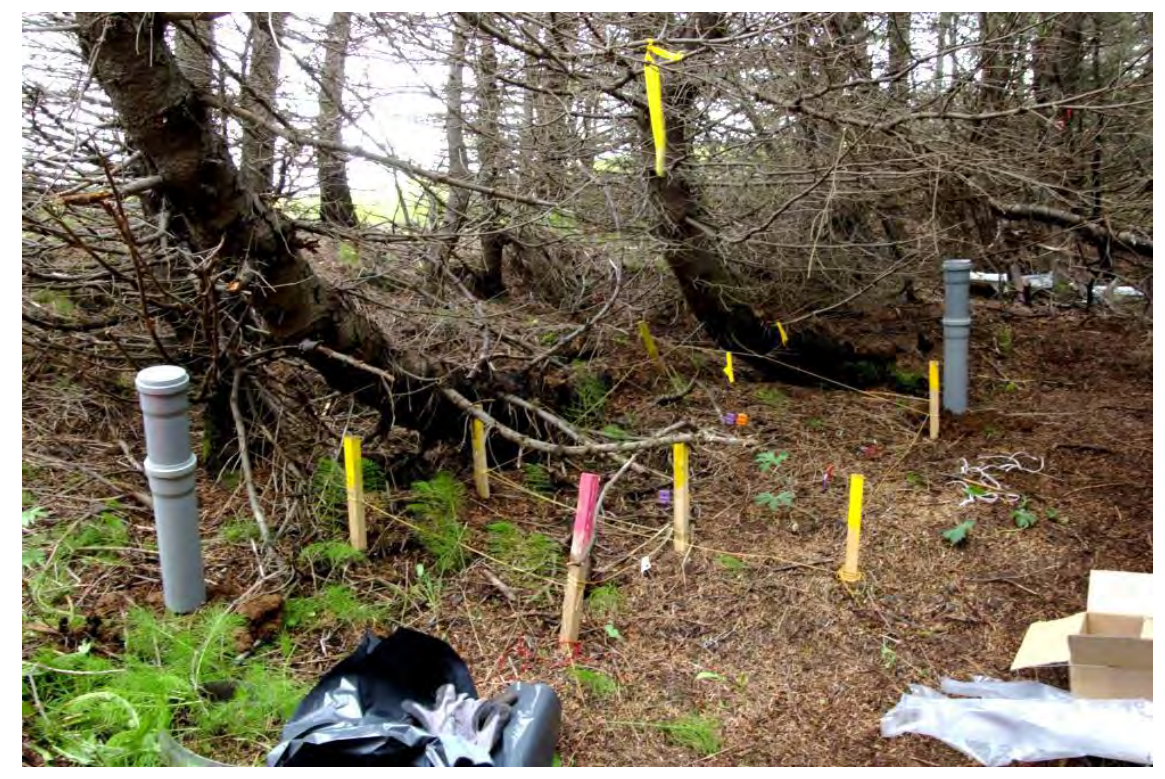

\subsubsection{Network: Forestry and Water network under the EU Strategy for the Baltic Sea Region.}

- Activity: Development of a network and creation of a platform for deeper cooperation on Forestry and Water Protection among the BSR countries including Russia.

- Year: 2014.

- Responsible actor: Linnéa Jägrud, The Swedish Forest Agency.

- Participating countries: Nordic and Baltic countries incl. SNS networks.

- Output: Network meetings, excursions, plans for project development.

- Measure in RSD: 5. 


\subsubsection{SNS network: Nordic Forest Water Mercury Network (NorForM)}

- Activity: Network, with the aim to better understanding of the connections between forestry operation and input of mercury to aquatic systems.

- Year: 2010-2014.

- Responsible actor: Kevin Bishop, SLU, Sweden.

- Participating countries: Sweden, Finland, Norway, N UK, Scotland, NW Russia, and Ireland.

- Output: International workshops, scientific publications and PhD work. Final reports submitted yearly to SNS. ${ }^{24}$

- Measure in RSD: 5.

\footnotetext{
${ }^{24}$ Yearly reports: http://www.nordicforestresearch.org/wp-content/uploads/2011/03/Network-activityreporting-2010_NorForm.pdf; http://www.nordicforestresearch.org/wp-content/uploads/2011/ 03/Network-activity-reporting-2011_NorForm.pdf; http://www.nordicforestresearch.org/wpcontent/uploads/2011/03/Network-activity-reporting-2012_NorForm.pdf
} 



\section{Overall Reflections}

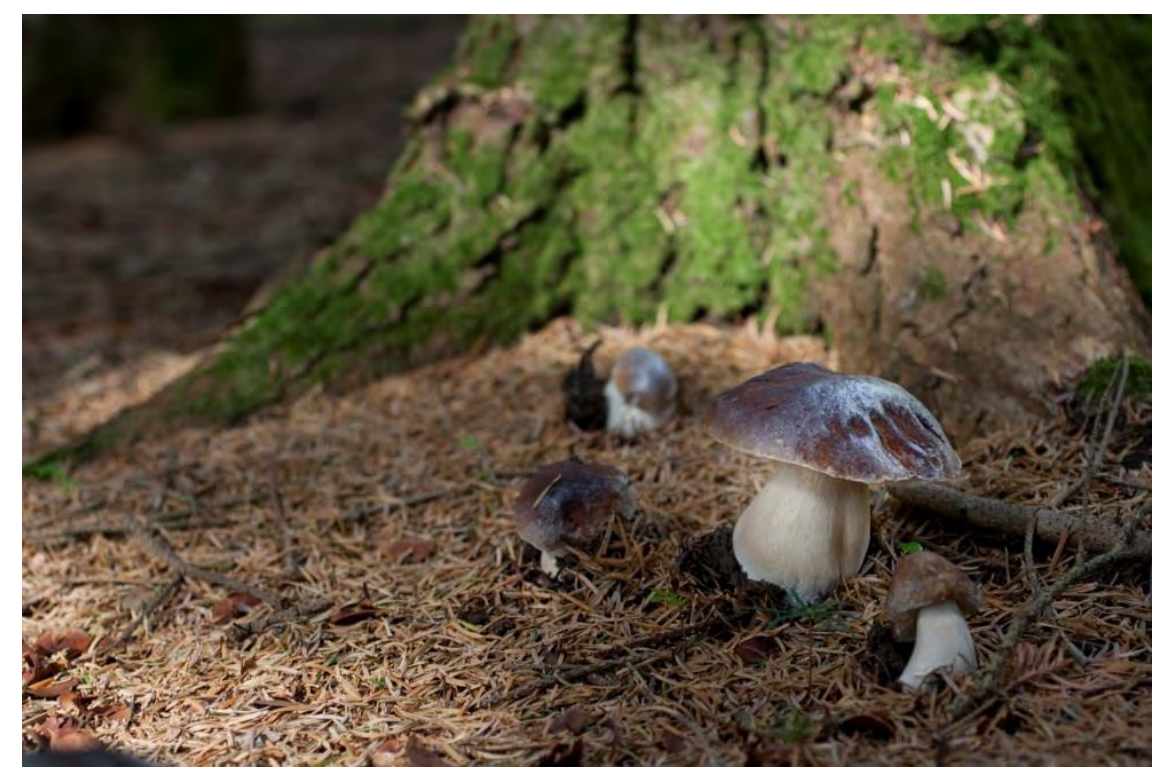

Overall, the feedback from the respondents was that the SD and the work following has provided a strong postive input to Nordic forest cooperation and has been used as model for other projects and programs within Nordic co-operation.

As in 2008, sustainable forestry, with a focus on water resources, climate change and generation of renewable raw material, remains a very relevant topic and has been reflected in the work of the forestry sector of the NMR. This can for example be seen in the new theme project during the Icelandic presidency of NMR in 2014 with Iceland's presidency programme Vigour - Vitality, ${ }^{25}$ which emphasises utilising and promoting the opportunities inherent in the resources, natural environment, expertise and human resources of the Nordic countries. An

25 http://www.norden.org/da/publikationer/publikationer/2013-770 
important part of that programme is the project WoodBio that will focus on production of wood biomass as renewable biological resources. ${ }^{26}$

As a follow-up to the SD, NordGen Forest has recently undertaken a questionnaire to survey the preparedness of Nordic forestry to climate change. Some preliminary results from the questionnaire will be published in the Annual Review of NordGen this year. One important finding is that there is an information deficit with respect to climate change issues, and in particular there is a need for translating scientific results to the decision-making levels in forestry.

${ }^{26}$ http://www.woodbio.com/ 


\section{Concluding Remarks}

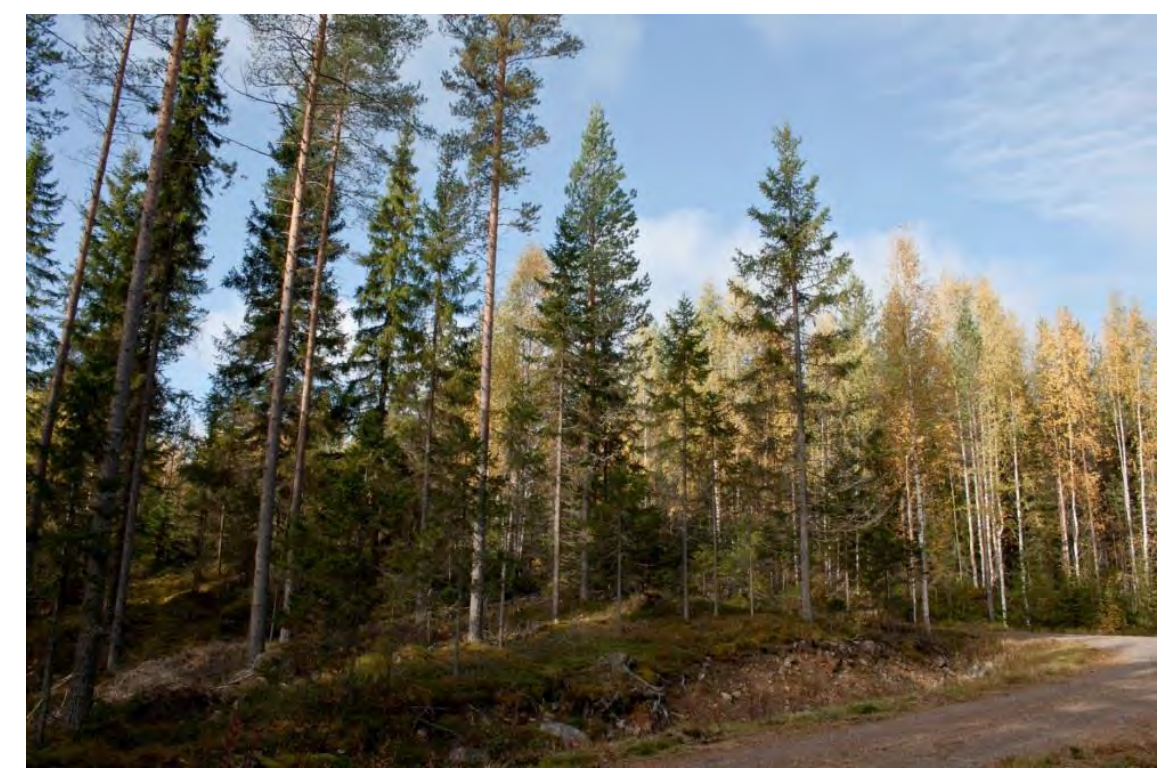

The Nordic region is quite homogeneous in many aspects, e.g. in culture, lifestyle and political system, as reflected in the establishment and importance of the Nordic Council of Ministers. However, a great difference can be seen in the natural environment, not the least in forest cover, that ranges from less than $1 \%$ up to $75 \%$ of countries' land area within the region. This difference is caused by large scale deforestation in the history of some countries, while others were able to maintain or increase their forest cover. Despite this dissimilarity, or maybe owing to it, Nordic forest cooperation is important, both inside and outside the Nordic countries. Co-operation in forestry was already established when the Nordic Council of Ministers was set up in 1971. For example, the predecessor of SNS was founded as a body of the Director Generals of the forest research institutes within the Nordic countries, since it was considered valuable for people to meet and discuss issues of common interest.

The differences between the countries, for example in the time-span that afforestation has taken place, gives unique opportunity to transfer knowledge and experience from one region to another, therby supporting those regions/countries that are beginning to build up their forest 
resource. This was highlighted in the Nordic project "Affornord" that studied the effects of afforestation on ecosystems, landscape and rural development in the years 2004-2006.27

It is not only the less forested regions that benefit from Nordic forest co-operation, since the the more dominant Nordic players in the field of forestry, also benefit from stronger co-operation. Focusing on forest issues with specific Nordic relevance can make a broader international impact for points of view shared by these countries possible. Technologies used in forestry and forest operation also have a solid Nordic base and the future competitiveness of Nordic forests and forest products relies not least on the success of Nordic R\&D.

One of the benefits of co-operation within the Nordic forest sector is the high number and diversity of participants. Researchers in the Nordic countries collaborate through SNS by way of networks and research projects, students and teachers through the NOVA university network ${ }^{28}$ and witin NordGen Forest where conservation and use of forest genetic resources is highlighted. Even though this report has focused on collaboration within or funded by the NMR, the collaboration is not restricted to those organs. For example, national organizations of Nordic forest owners have maintained close cooperation since 1946 and founded Nordic Family Forestry. ${ }^{29}$ It should be a priority in the future to reach out to as many actors in Nordic forestry as possible when organizing and formulating the stratecic of forestry in the Nordic countries.

It seems clear that the co-operation in forestry between different countries and different actors within the Nordic region is important and has been successful, as indicated in a recent evaluation of Nordic Forest Research Co-operation, ${ }^{30}$ where SNS was praised for the success in bringing people together and enabling cooperation. This was more apparent when the Nordic countries were recently given the responsibility to co-ordinate, on behalf of EFI, forest research throughout the whole of Northern-Europe, leading to the set up of EFI-NORD. ${ }^{31}$

\footnotetext{
${ }^{27}$ Halldorsson, G, E. S. Oddsdottir, and B. D. Sigurdsson, (eds.). Affornord - Effects of Afforestation on Ecosystems, Landscape and Rural Development. Vol. TemaNord2008:562. Copenhagen: The Nordic Council of Ministers, 2008.

${ }^{28} \mathrm{http}: / /$ www.nova-university.org/

${ }^{29} \mathrm{http}: / /$ www.nordicforestry.org/default.asp

30 Indufor (2012). Nordic Forest Research Co-operation Committee (SNS). Evaluation of Nordic Forest Research

Co-operation. Final report. http://www.nordicforestresearch.org/wp-content/uploads/2011/

02/Indufor_Final-Report_Evaluation-of-SNS.pdf

31 http://www.efinord.efi.int/portal/
} 
The key to a successful operation is a clear political vision, which in the case of SD was outlined by the Nordic forestry ministers. The followup work of the ad-hoc committee and publication of the recommendations facilitated and encouraged the organs within the Nordic countries to incorporate and carry out projects in harmony with the vision. Based on the experience with the SD and following work, it seems important that the forestry ministers continue to take an active part in visualizing where the Nordic cooperation should head into the future. 



\section{Sammendrag}

I 2008 fremlagde skovbrugsministerne i de nordiske lande Selfossdeklarationen om bæredygtigt skovbrug i Norden, hvor vigtigheden af skoven i den globale klimaændring og dens betydning for biodiversitet, rekreation og som en ressource for økonomisk udvikling eblev understreget. I en rapport som blev udigvet indenfor TemaNord serierne gav et ad-hoc-udvalg anbefalinger om, hvordan man gennemfører denne hensigt af erklæringen. Anbefalingerne var to foldige, politiske anbefalinger til de nordiske samarbejdsstrukturer og mere direkte foranstaltninger, der omfattede forskellige aktiviteter, der skal gennemføres af forskellige nordiske aktører.

Denne rapport har til formål at reflektere over resultaterne af Selfoss deklarationen og den efterfølgende rapport. Spørgsmålet er om skovbrugssektoren fokuserede på beslutningen som blev anerkendt i erklæringen/deklarationen og desuden hvordan det påvirkede skovbrugssektoren i de nordiske lande.

Mere end 20 aktiviteter fandt sted i forbindelse med Selfoss deklarationen. Resultaterne af disse aktiviteter er variable og deres tilgængeligehed er forskellig men der, findes rapporter for de fleste online og $\mathrm{i}$ mange tilfælde er artikler i peer -reviewede tidsskrifter også tilgængelige. Det synes at være en generel opfattelse, at Selfoss -erklæringen igangsatte en masse aktiviteter og skarp tiltag i organiseringen af skovens forskningssamarbejde, på tværs af landegrænserne indenfor de nordiske lande. Iværksættelse af nye netværk og forsættelse af ældre netværk har lettet udvekslingen af idéer og styrket samarbejde mellem forskere i de nordiske lande og i nabolandene.

Nøglen til en vellykket operation er en klar vision, som i tilfældet af Selfoss -erklæringen blev skitseret af de nordiske skovbrugsministre. Det opfølgende arbejde i ad-hoc- udvalget og udgave af anbefalingerne gjorde det nemmere for og opfordrede de nordiske organisationer til at gennemføre projekter i harmoni med den vision. Baseret på denne erfaring er det vigtigt, at skovbrugsministerene i fortsætter ad tage aktiv del i at visualisere hvorhen det nordiske samarbejde bør stræbe mod fremtiden. 



\section{Appendix: Letter to SNS secretariat, NordGen Forest, members of EK-FJLS skog and the NMR office, emailed in January 2014}

Dear Nordic forestry colleagues;

The Icelandic Presidency in the Nordic Council of Ministers (NCM) 2014 has initiated a project with the aim to sum-up and report on the achievements of the implementation of the Selfoss Declaration, given by the Nordic Forestry Ministers in 2008. The project is supported by NCM. The idea is that the report summing up and analyzing the achievements, will presented to the MR-FJLS meeting in Iceland in June 2014. Coincidentally, that meeting will also take place in Selfoss town!

As you recall, there was established Nordic ad-hoc group that developed recommendations to Nordic forestry on the basis of the Selfoss declaration. The report was published in 2010 and is available here: Implementing the Selfoss declaration. Recommendations to Nordic Forestry. www.norden.org/is/utgafa/utgefid-efni/2010-554/at_download/ publicationfile

We are therefore contacting you for information on the achievements of the implementation of the recomendations outlined on the basis of the Selfoss declaration.

We would kindly like to get two sorts of feedback from you.

Firstly, reflections (not long) on the overall usefulness of the Selfoss declaration work and the impact this has had in general in your field (country or Nordic organization)?

Secondly, we would like to get more detailed information on the implementation of the individual measures outlined in the SD recommendations report. The list of activities and responsible actors is attached to this email. This applies especially to SNS, NordGen Skog and NMR that were assigned the task to implement many of the measures. 
We would like get information on issues like:

i. If and where the activity took place.

ii. Who was responsible for carrying out the activity (e.g. grant holder, project manager).

iii. Participants (numbers, countries).

iv. The outcome of the project (reports, projects, policy).

v. Has the outcome been useful to the forest sector, and if so, how?

vi. Any further work using this activity's outcome.

vii. Other issues.

The project manager, responsible for this work is Dr. Edda S. Oddsdottir senior researcher at the Iceland Forest Service Research, Mogilsa. Edda will collect, compile, analyze and write up the report. Please respond to her before 15th February, edda@skogur.is or mobile: +354 8924503.

Hopefully this finds you well.

Please don't hesitate to take contact in case of any information or assistance needed. 
Ved Stranden 18

DK-1061 Copenhagen K

www.norden.org

\section{Selfoss Declaration Achievements Report}

This report reflects on the achievements of the Selfoss Declaration on sustainable forestry in the Nordic region, made in 2008 by the Ministers of Forestry in the Nordic countries and the following reccommendations on how to implement the intention of the declaration. The question is, did the forestry sector focus on the resolution acknowledged by the forestry ministers in the Declaration, and furthermore, how did it affect the forestry sector in the Nordic countries. The Selfoss Declaration initiated a lot of activities, financed with funds from the Nordic Council of Ministers and incisive actions in organizing the forest research cooperation across national boundaries within the Nordic neighbouring countries. Based on this experience, it seems important that the forestry ministers continue to take an active part in visualizing where Nordic cooperation should head in the future.

TemaNord 2014:555

ISBN 978-92-893-3802-8 (PRINT)

ISBN 978-92-893-3804-2 (PDF)

ISBN 978-92-893-3803-5 (EPUB)

ISSN 0908-6692
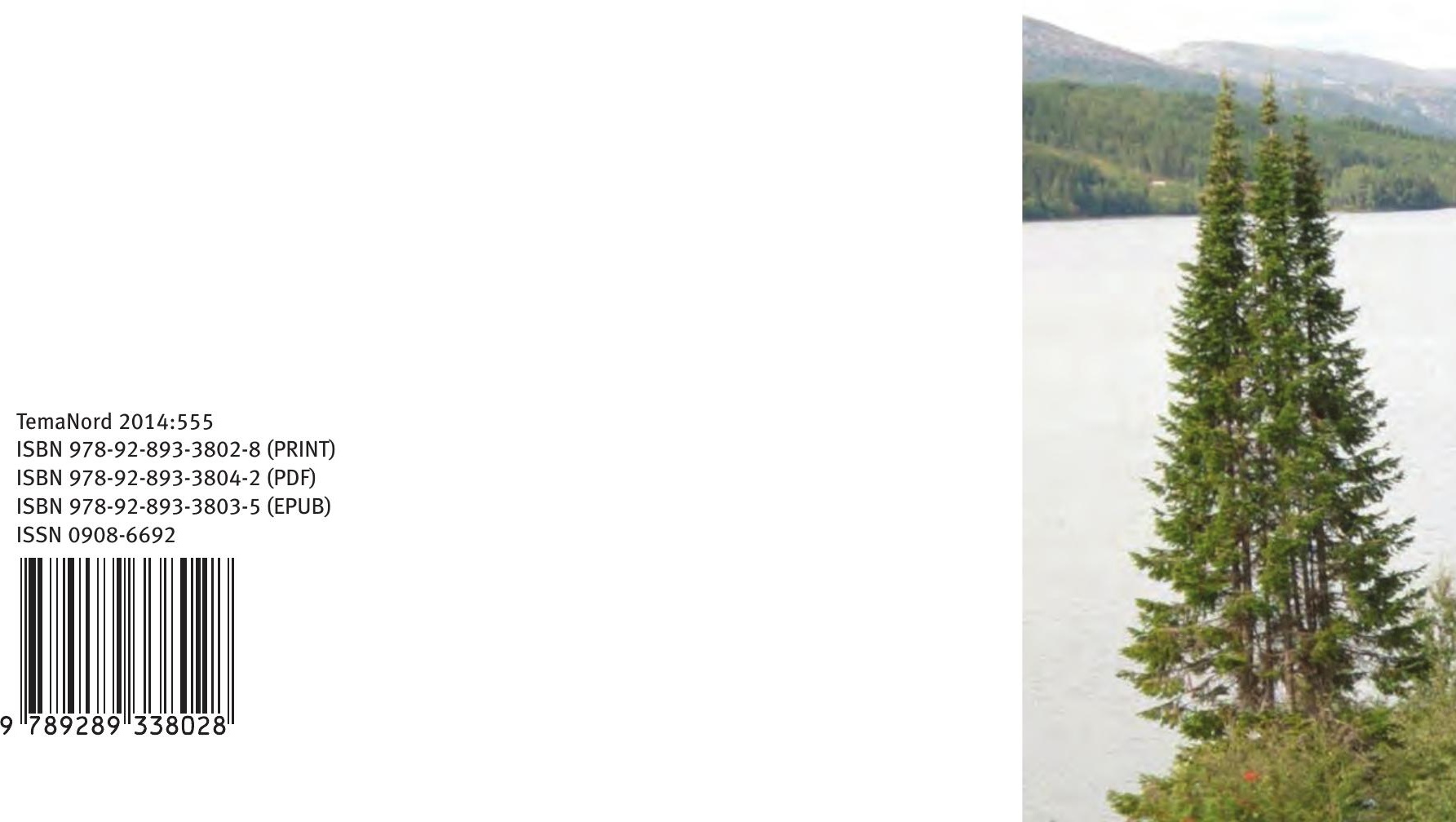